\title{
BANKING SECTOR CRISES AND INEQUALITY
}

\author{
Patrick Honohan*
}

\begin{abstract}
An apparent temporary narrowing of income inequality has been observed during several recent banking crises. But it would be a mistake to conclude that such crises don't matter for the poor. For one thing, the correlation is not strong, and the opposite pattern has also been present. Besides, the poor are much less able to absorb a cut in income: safety-net policies are urgent during a downturn even if the gap between rich and poor has temporarily narrowed. More fundamentally, distributional shifts during the crisis itself may be less important than the fact that underlying financial policy and infrastructures conducive to crisis can also be associated with more unequal societies.
\end{abstract}

World Bank Policy Research Working Paper 3659, July 2005

The Policy Research Working Paper Series disseminates the findings of work in progress to encourage the exchange of ideas about development issues. An objective of the series is to get the findings out quickly, even if the presentations are less than fully polished. The papers carry the names of the authors and should be cited accordingly. The findings, interpretations, and conclusions expressed in this paper are entirely those of the authors. They do not necessarily represent the view of the World Bank, its Executive Directors, or the countries they represent. Policy Research Working Papers are available online at http://econ.worldbank.org.

*The World Bank. phonohan@,worldbank.org. Thanks to Stijn Claessens and Sergio Schmukler for helpful comments. 


\section{Introduction}

Financial sector crises are often especially damaging to the poor, derailing education and preventive health-care and setting back the development process. In addition, elite groups at the top of the income and wealth distribution often escape the worst of the crisis, by exporting capital ahead of the crash and seeing their debts written off. On the other hand, some have noted cases where inequality has narrowed, for example where higher income groups with closer ties to formal finance suffer when banks fail.

So which is it: does a pro-poor financial sector policy need to pay special attention to financial sector crises, or are they more a matter of concern to higher income groups? This policy question is more complex than might at first appear: it has both short-term and long-term aspects.

Though confirming that measured income inequality has narrowed in the immediate aftermath of several banking crises, this note dismisses any implication that such crises are unimportant for anti-poverty policy. The ultimate causes of crises vary, and each different causal path may be expected to have different consequences for poverty.

If the crisis is accompanied by a general economic downturn - which is not always the case - there will be an increase in poverty. But the short-run impact of the breaking of a crisis can often be associated with an improvement in inequality as the higher income groups temporarily experience disproportionate losses of income. After all, many of the syndromes that lead to major or repeated financial sector crises are logically associated with more unequal societies: systemic failure can undermine the privileges that have been built in. Of course, it is cold comfort for the poor when a general economic downturn reduces the income of the rich by even more: focusing on (relative) inequality can be misleading in such circumstances if our concern is for the welfare of the poor.

When the crisis hits, the consequences for the income level of different groups depends on the economy's capacity to absorb shocks, a capacity which is certainly influenced by the effectiveness of financial structures, but which is also strongly influenced by, for example, the flexibility of labor markets. Safety net policies and the government's willingness and capacity to implement, protect and adapt such policies is also a crucial determinant of the distributional fall-out of a crisis.

In the longer run, if the crisis leads to a sufficient reconfiguration of power and policies as to result in a more effective and more growth and equality-promoting financial system, the long-run position of the poor could be greatly improved. On the other hand, there could be long-lasting adverse effects of the shock on escape-from-poverty probabilities.

The growing professional interest in measuring distributional changes worldwide and the growing availability of data make it possible to attempt a quantitative approach to understanding these issues, even though the precision of available data is not high, and even though making comparisons between successive survey-based inequality estimates is made hazardous by the likely size of random measurement error. In this context, it should be noted that measuring the overall economic costs of banking crises has proved 
to be particularly difficult and controversial. No such measures command general assent among scholars, and therefore there is no secure foundation for going the further step of assessing distributional consequences.

Although, as will become evident, individual crises have been analyzed in detail, crosscountry empirical studies of distributional aspects of banking crises per se have been scarce. Most of the comparative work on crises (for example Lustig, 2000) has had a wider scope, including also macroeconomic and currency crises. Indeed, it is hard to disentangle the effects of currency and banking crises which often coincide. An exception is Halac and Schmukler's important (2004) paper which specifically focuses on the financial sector channel.

In addition to exploring these issues at a conceptual level (Section 2), this paper reviews some of the empirical evidence on these issues. Documented cases from each continent where inequality has declined are reviewed in Section 3; the case of Indonesia in some detail in the Annex. Cross-country evidence is marshaled in Section 4: systematic and robust regression relationships remain elusive, likely the consequence not only of the conceptual complexity but also of what proves to be still a small and problematic database. Section 5 draws some policy conclusions.

\section{Crises and their channels of impact on inequality}

In considering the policy implications of financial crises it is important to bear in mind that the crisis itself not a policy tool to be turned on or off: the frequency, severity and timing of financial sector crises are the outcome of the interaction of various forces, including prior policies and institutional structures, as well the incidence of exogenous shocks. In searching for relevant policy lessons, we need to distinguish between these forces, and focus on the causal factors that may be subject to policy action.

This section looks at three conceptual issues. We begin (Section 2.1) by clarifying the scope of the inquiry and explaining why the focus of the paper is on banking crises rather than on economic and financial crises more generally. Section 2.2 discusses the inadequacy of relative inequality measures for judging the welfare impact on the poor, both in the short- and the long-term. Section 2.3 reviews the different channels through which a crisis may affect inequality and the poor, observing that a channel-by-channel analysis needs to be complemented by an overall macro view.

\subsection{Banking and other financial crises}

This paper is largely about banking crises, excluding many wider events that are often included under the heading of financial crises. The latter term is often used in a very broad sense to include the abandonment of an exchange rate peg or other sharp exchange rate movements, sharp movements in stock prices or in interest rates, and the associated macroeconomic turbulence. For those focused on Latin America, the distinction may seem academic. But taking a wider global view, banking systems have survived many currency and macroeconomic crises without systemic failure. 
To be sure, almost any shock of macroeconomic importance, including non-economic shocks (such as earthquakes and hurricanes) will tend to reflected in some financial asset prices. ${ }^{1}$ But these financial asset price movements can be thought of as having the function of transmitting and absorbing these shocks. Large asset price movements may reflect effective financial market functioning - not failure. But a severe shock may result in even larger asset price movements associated with financial market failures, as when technical or information failures make prices deviate from a rational expectations equilibrium. Events even in advanced markets such as the October 1987 New York stock market event or the dot.com bubble (perhaps most dramatically exemplified by the collapse of the German Neuer Markt in 2000-1) are cases in point. Distinguishing such asset-pricing market failures from rational market movements is highly problematic and controversial, however.

Short of entering this controversy, the researcher is faced with the choice of either analyzing all assets involving financial asset turbulence or narrowing the focus considerably. Clearly, if we were to count as financial crises all large events that are accompanied by financial asset price movements, we would widen the scope of the study to all economic crises, thereby losing the intended focus. Other studies of the poverty and inequality impact of crises have chosen different dimensions of crisis: for example, Baldacci et al. (2002), define crisis as a large exchange rate depreciation, following Frankel and Rose (1996). Lustig's influential (2000) review of Latin American experience is also based on a wider crisis concept.

Instead, the present paper focuses more narrowly on failures in the functioning of financial sector intermediaries, primarily banks, in the hope of identifying more precise conclusions. Thus we focus on situations where financial intermediaries suddenly fail to perform their normal functions: depositors are unable to access their funds, ${ }^{2}$ or if they are, it is only because of exceptional steps taken by the central bank or other monetary authorities. Wholesale or retail payment instructions fail to be delivered. Credit flows dry up and facilities cannot be renewed. Equities cannot be sold promptly on the organized market. Note that isolated failures of particular institutions do not add up to a systemic financial crisis unless these institutions count for a sizable fraction of the market - not less than 10 percent, say.

\footnotetext{
${ }^{1}$ To a degree, this depends on the degree of development of financial asset markets. If the shock in question has macroeconomic importance, it will likely affect the equilibrium real exchange rate, profit flows for important sectors and the ability and willingness of the government to finance its spending plans without reliance on the inflation tax and the nominal interest rate required to achieve the monetary authorities' goals. In an economy with extensive traded securities, the prices of various financial assets will embody the market's evaluation of a stream of future payments which will be sensitive to these consequences of the shock. Where markets are less well-developed, it is even possible that price movements for the assets that are traded will be even larger.

${ }^{2}$ Or policyholders find that insurers are unable to meet the contingencies envisaged in the policies. Although there have been a number of large insurance company failures worldwide, insurance is so much smaller than banking in almost all countries that insurance has not been at the centre of any of the financial crises conventionally regarded as systemic.
} 
Banking crises in this sense can be triggered by external shocks, and in extreme cases (such as the Argentine event of December 2001) may in fact be caused by the shocks. However, the experience of many countries shows that banking systems that are wellcapitalized and managed can absorb even sizable external shocks. Even when triggered by exogenous shocks, we should regard most systemic banking crises as having financial sector policy causes.

Most commonly, then, it is latent weakness in financial sector policies and institutions that is uncovered by the economic downturn associated with an adverse shock, and its revelation can lead, through credit, confidence or other channels, to a deepening of the downturn itself. If financial system policies and structures had been more robust, they should have withstood the shock. Distinguishing the effects of the financial weakness per se from those of the non-financial shock is by no means straightforward. How bad would things have been if the financial sector had survived the wider adverse shock? The debate on how to measure the economic costs of banking crises remains quite unsettled for this precise reason.

\subsection{Thinking differently about short-term and long-term effects}

A distinction must be made between medium-term and short-term aspects.

- The short term relates to the period immediately surrounding the denouement of the crisis. This is the fast-moving stage that may be accompanied by sharp exchange rate, interest rate and stock market movements; a wave of bankruptcies of firms, nonfinancial and financial alike; payments system failure; depositor panic; bank closures; soaring unemployment; and abrupt shifts in relative prices of foodstuffs, and in the purchasing power of wages and pensions. The short term is counted in months or quarters, and will often be played out within two or three years.

- The medium term embraces the pre-crisis period during which hidden imbalances that would cause or exacerbate the crisis are being accumulated. It also embraces the resolution phase when the direct financial costs of the crisis are allocated and when the institutional and often political reconfigurations that result from the crisis are being put into place. The duration of the medium term, from pre-crisis to resolution, could be as long as a decade or more.

Short-term: even an inequality-reducing economic decline can hit the poor more than most

In the short term, inequality of both income and expenditure often declines. In the case of a generalized economic downturn associated with a financial crisis, while mean income typically falls at all deciles, ${ }^{3}$ the formal sector of the economy may be hit more directly, and wage rates for the high skilled may fall more than most.

\footnotetext{
${ }^{3}$ Though not necessarily for all individuals. There are gainers from the pattern of relative price changes, and these may be at all income levels, from smallholder producers of food (if the relative price of food climbs during the crisis), to bankruptcy lawyers.
} 
But even if measured inequality declines, that is far from implying that financial crises are of less concern to the poor. For one thing, many common measures of inequality are insensitive to the disproportionate welfare impact of small income changes on the poor.

Specifically, linear measures of inequality, including the Gini, interquartile range, etc. fail to take account of the fact that the poor are less able to absorb income losses. A linear metric of income as welfare is particularly inadequate to approximate the distribution of welfare losses when poor people close to subsistence are experiencing sharp declines in wage rates and in the price of their produce. Concerns of this type can be partly addressed by considering the allocation of household expenditure among different product classes. They also motivate nonlinear measures such as the Atkinson index and poverty headcount, poverty gap and other members of the Foster-Greer-Thorbecke class.

In addition, faced with lower real wage rates, poor people will try to substitute more hours of labor to maintain spending power for necessities, so that actual cash income (or expenditure) changes will understate the decline in full income and as such in welfare. By scrimping on preventive health care, education and other investments, the poor may forgo disproportionately large returns on such investment, whether rationally or because of information imperfections (not fully understanding the forgone opportunities) or interhousehold issues (the future welfare of children or spouses not fully internalized by the household spender).

Because of the nonlinearity of the welfare impact of income decline, aggressive safety net measures (such as those discussed in Ferreira et al., 1999, or Manuelyan-Atinc and Walton, 1998) are clearly needed to limit the impact on the poor of an economic downturn. As a result, if such policies are effective, income inequalities should narrow in the short run; the extent that they do not can be regarded as an indication of the inadequacy of the safety net.

Long term: the financial crisis can be the first step towards a more healthy regime As for the medium and long term, the question is subtly changed. From this perspective the crisis can be seen as part of a process whereby unsound financial structures and policies are exposed, hopefully leading to their resolution on more healthy basis. If recent results showing that financial sector development is correlated with improved income distribution are any indication, then this medium-term dialectic should imply a gradual post-crisis improvement in income distribution. That presumes that the resolution of the crisis is indeed done on a sustainable and sound basis, which is not always the case, as can be seen from the fact that many countries have experienced several successive financial crises.

All going well, we would expect an improvement in income distribution from an unsound pre-crisis financial sector policy (with, for example, undercapitalized private banks lending recklessly to insiders in an under-regulated environment with weak enforcement of property rights and deficient information infrastructures, or dysfunctional government banks lending in accordance with political directives) to a cleaned-up, well-capitalized and contestable system supported by adequate information and legal infrastructures. All 
too often, though, crisis resolution will fall short of this ideal, in which case the distributional improvements will not be seen either.

Both short and long-term perspectives foresee potential improvements in income distribution around financial sector crises, though on different timescales, and depending (in the first instance) on the nature of the economic system's crisis absorption capacity, including the safety-net response of government and (in the second instance) on whether the crisis does in fact achieve the hoped-for cathartic effect.

\subsection{Channels of effect}

Banking crises come in different varieties and with different degrees of severity (Honohan, 2000). Some are resolved without the economy being pitched into a macroeconomic recession. These would include several cases where government-owned banks were revealed to have incurred severe losses on their loan portfolio, losses which were eventually made good by government recapitalization without an intervening loss of confidence by depositors or by the holders of local currency or government debt. In these cases, the costs flow through fiscal channels, affecting the needed balance between tax revenues and expenditures which can have distributional consequences as well as potentially affect long-term growth rates through the deadweight cost of taxation.

Other banking crises have been associated with major macroeconomic volatility in a way which, as mentioned, often defies analysis of causality: economic downturns trigger the banking crisis, or its recognition; the scale of the banking losses in turn affects confidence and may deepen the recession and drive down the external and internal value of the currency. Here some distributional effects may still come through fiscal channels (including the transfer of fiscal resources to persons who are, directly or indirectly, bailed out), but there are several additional channels: loss of employment; loss of current and prospective business profits; relative price changes, including changes in real wages, capital losses and gains on unhedged foreign exchange positions.

Taking stock, then, consider the following checklist of channels through which households can be adversely affected by a financial crisis. ${ }^{4}$ We rank them in order starting with those most closely related to the banking failure itself.

(a) Loss of deposits in a failed banking institution

(b) Loss of employment or earnings directly due to (i) disruption of the payments process, (ii) the bankruptcy of financial institutions (for employees and other stakeholders of these institutions) or (iii) the interruption of credit flows (for borrowing clients with information capital invested in the failed financial institutions)

(c) Tax increases or curtailment of public spending due to fiscal cost of bail-outs of financial firms or their customers

\footnotetext{
${ }^{4}$ Many previous studies provide a similar checklist. The present one is specifically adapted to banking crises.
} 
(d) Temporary or permanent changes in relative prices of (i) consumption goods, (ii) wage rates, (iii) production goods (iv) asset prices, that arise through knock-on effects on the rest of the economy

(e) Involuntary unemployment if the crisis leads to a generalized economic downturn.

Some relative price shifts and some changes in fiscal policy resulting from the crisis can also benefit some households. For instance, a program of debtor relief may be adopted which conveys considerable benefits to debtor households.

\section{Impact on depositors}

Some indications of the distributional implications of the first channel can be calculated from surveys of financial assets holdings. This has been done for four Latin American countries by Halac and Schmukler (2004). For example, in their data the top decile of income earners own 36 percent of the total number of household deposit accounts and the bottom half of the income distribution own only one of every six accounts.

Unfortunately, we do not know from this evidence what is the distribution across income deciles of deposits by value. ${ }^{5}$ We do know that only about 24 percent of the adult population has a bank account in Mexico City. Even lower percentages are reported elsewhere. ${ }^{6}$

It might, therefore seem that loss of deposits is likely to reduce inequality. If so, this might be taken as evidence that bailing-out depositors is a regressive policy. However, in order to see just how regressive, the skewed distribution of bank deposit holdings needs to be compared with the skewed distribution of household incomes. After all, the top decile of income earners in the Mexico receives about 42 percent of household income whereas the bottom quintile receives little more than 3 percent of household income. Thus the departure from proportionality represents only a small fraction of the total sums disbursed in the bail-out.

Ironically, a policy which begins by financing liquidity problems of the banking system (and foreign exchange outflows) arising from depositor withdrawals but is then followed by suspension and not paying the remaining depositors (or paying them only in depreciated currency) after the bank fails, or the currency collapses, is likely to be much more regressive. As is comprehensively documented for the cases of Argentina, Ecuador and Uruguay by Halac and Schmukler, it is the largest depositors who withdraw first (even while smaller depositors are still adding to their deposit holdings). Likely the large and well-informed depositors who withdraw early are mostly corporates, but wealthy individuals will also be in this category. ${ }^{7}$ Their relative gains are unlikely to show up in surveys of income and expenditure.

\footnotetext{
${ }^{5}$ This information is available for some advanced economies. Interestingly, bank deposits form a much lower proportion of financial asset holdings for higher income deciles in advanced economies, reducing the dispersion of deposit holdings.

${ }^{6}$ At one extreme, a recent Tanzanian survey found that 94 percent of households had no bank deposits.

7 In Uruguay, most of the withdrawals were by non-residents, presumably from Argentina.
} 
Halac and Schmukler's work points to the value of using survey information on financial service usage in assessing the effects of financial crises. A growing number of household surveys around the world contain information on access to financial services, though not enough to provide a range of "before and after" cases for econometric work. In particular, LSMS surveys, some of which contain quite detailed information on household access to certain financial services, are conducted rather infrequently, with the result that changes between before and after crises cannot readily be read off the findings. ${ }^{8}$ However they can provide a benchmark for the before- or after-crisis distribution of financial access. Table 1 provides a list of recent LSMS surveys containing financial sector information ${ }^{9}$ together with the dates of the most recent banking crises reported for these countries. (This information is not pursued further in the present draft of this paper, but may be useful for future work.)

\section{Tracking other channels}

There is no comparably clearcut way of isolating the likely distributional effects of the remaining channels. This is especially true of the last two, inasmuch as they could be experienced as a result of non-financial shocks. How is the analyst to distinguish between job losses that are due to a disruption of the payments process and those arising from a general downturn in the rest of the economy?

One approach involves identifying characteristic patterns of relative price change following a banking crisis. A temporary surge in inflation is a common occurrence following banking crises that have been associated with macro downturns (though this is not necessarily the case, and is not always observed). Inasmuch as inflation is typically inequality-increasing, this can be regarded as inequality increasing. Real wages have often fallen in such circumstances, and Diwan (2001) has shown a tendency for the share of labor in national income to decline during financial crises (counting currency crises as well as banking crises); however, sharp macroeconomic downturns have often been associated with a relative decline in the wages of highly-skilled workers, so it is not clear that wage movements will be inequality increasing. ${ }^{10}$ Interest rate levels and spreads also typically increase.

An alternative to decomposing the effects into different channels is the holistic or reductionist approach of examining directly the movements of inequality and poverty around the time of crises.

\footnotetext{
${ }^{8}$ It would, for example, be useful to discover whether spending patterns of households with better access to finance before the crisis are better insulated from the crisis, but this cannot readily be detected without having a post-crisis survey as well.

${ }^{9}$ In addition some specialized financial sector usage surveys also explore these areas (cf. Honohan, 2004).

${ }^{10}$ Sanchez and Schady (2003) document this pattern in their study based on household surveys for six Latin American countries. Their sample includes "Chile in 1972-75, and again in 1982-83, Argentina in 19881990, Brazil in 1981-83, and again in 1990-92, Colombia in 1999, and Mexico in 1995. With the exception of the Mexican tequila crisis of 1995 and the Colombian recession of 1999, all of these crises have been associated with pronounced decreases in the relative demand for the most educated workers." Sustained downturns may, however, be associated with increases in inequality (cf. Inder, 2004).
} 


\section{Some documented cases}

\section{Indonesia}

Here an important and well-documented case is the Indonesian crisis of 1997-9. Detailed analysis of household surveys taken just before, during and after the crisis displays graphically how living standards fall across the board, but tells a more mixed story about relative effects (Frankenberg et al, 1998, Strauss et al. 2004 - see Annex 1). The indicators are that, while absolute poverty rates soared from perhaps 15 percent of the population to 33 percent, the (relative) distribution of income became less unequal. ${ }^{11}$ Also, remarkably, three years after the crisis hit, absolute poverty rates had dropped back below their pre-crisis levels.

Is the Indonesian case representative? Because of the nature of the data collected, the channels of influence from financial firm failure to poverty are hidden. Huge changes in relative prices, and some deterioration in the quality (and increase in the relative price) of public health services are the proximate causes of changes in poverty and inequality as measured in the Indonesian household data. These relative price changes were closely linked with the very large exchange rate movements that characterized the Indonesian crisis. Food prices in particular adjusted more and faster than other prices. In addition, there were widespread business failures and civic disturbances. Other financial crises have not been associated with as much macroeconomic and political turmoil and with such sharp changes in relative prices. This is the first reason for skepticism about how readily one can generalize from the Indonesian experience.

But in addition, it is well established that large macroeconomic adjustments can be associated with relative price changes that actually benefit large segments of the poor population (Ferreira et al. 1999, Manuelyan-Atinc and Walton, 1998). The contrast between Latin American and African adjustments in the 1980s is often mentioned: the increase in producer prices for small African farmers resulting from real devaluations in several countries helped improve income inequality there, whereas Latin America experienced deteriorating income inequality. ${ }^{12}$

Third, the endogenous economic mechanisms for adjusting to shocks differ from country to country. For example, Behrman et al. (2000) show that labor market adjustment in the 1997-8 Thai crisis involved considerable increases in involuntary unemployment but no decline in real wage rates and no evidence of the increased employment that happened at

\footnotetext{
${ }^{11}$ Note, however, that, in contrast to the before-and-after comparison of measured inequality, the microsimulation model of Robilliard et al. (2002) implies that the pattern of price and wage changes, credit crunch, etc., of the Indonesian crisis would have increased inequality slightly (discussed further in the Annex).

${ }^{12}$ Lustig (2000) shows that widening inequalities were seen in 15 of the 20 macroeconomic crises which she studies from Latin America 1980-95. In a provocative and not unrelated analysis, Behrman et al. (2001) argue that financial liberalization contributed to the worsening of income distribution in Latin America in the 1990s. They regress the Gini, and the log-difference between the mean income of the top decile (or of the median income), and the mean income of the bottom 30 percent on a number of measures of policy, including an index of financial liberalization, as well as measures of inflation, macroeconomic volatility and the real exchange rate. The financial liberalization index, from Morley et al. (1999), is based on whether or not there were controls on deposit and lending rates, and on the ratio of reserves to deposits in the banking system.
} 
roughly the same time in Indonesia. These contrasts were already foreseen in Manuelyan-Atinc and Walton (1998).

Finally, even if the impact of crisis on market price and incomes was the same the world over, the ability and willingness of the government to maintain or improve the safety net is most unlikely to be.

For all of these reasons, generalization from the Indonesian experience should be done with care. Nevertheless, each continent has seen important recent crises for which studies suggest that they have also been associated with narrowing inequalities.

Mexico, 1994

Baldacci et al. (2002) present some detail on shifts in Mexican income distribution for the three Mexican National Household Income and Costs Surveys (ENIGH) 1992, 1994 and 1996. Poverty incidence increased dramatically in the immediate aftermath of the crisis moderate poverty (as nationally defined) jumped from 36 to 48 percent of the population and extreme poverty from 11 to 17 percent in the two years to 1996. Nevertheless, the lower deciles were not the worst affected in relative terms. The income share of the top decile fell from 44 percent to 42 percent, with gains in all of the other deciles (except the fourth). Accordingly, not only the Gini, but the Theil and Atkinson's indices (for parameters $0.5,1$ and 2) all show improvements. This holds for both the data on income and expenditure. Baldacci et al. also show that the change between 1992 and 1996 in the probability of being poor in Mexico is systematically related to geographical and age characteristics: households in Yucatan province, and in urban areas, and those with very young or very old heads, all displayed a heightened propensity to be poor. Transfers kept 6.1 percent of the population out of poverty in 1996, compared with 4.5 percent in $1994-$ suggesting little improvement in the scale or targeting of income transfers.

Actually, the Mexican case alerts us to just how severe are data problems on inequality from standard sources. Even as straightforward a question such as: "did the Gini coefficient increase in Mexico between 1994 and 1996" produces conflicting answers in the literature. Table 2 and Figure 1 show the trend in the Gini coefficient 1992-1998 as reported in different studies mostly based on the ENIGH. The apparently sizable increase in the Gini index in 1992-95 reported by the World Bank's Povcal is not confirmed by any of the other studies for the intervals 1992-94 and 1992-96. ${ }^{13}$ (This needs to be borne in mind in considering the findings of Section 5, which is based on Povcal data, though it does not use the offending 1995 Mexico observation.) ${ }^{14}$

Russia, 1998

Lokshin and Ravallion (2000) review the experience with the Russian crisis of 1998. Their major interest is in examining the role of the safety net in favorably impacting the distributional and poverty impact; they conclude that changes in the safety net had a

\footnotetext{
${ }^{13}$ Although included in Povcal, this 1995 estimate is annotated as "less reliable" in the WIID2 database.

${ }^{14}$ Using household panel data, Fields and Sanchez (2004) provide details on the Argentina case of 2001-2 suggesting that, although the Gini coefficient worsened, it was not those who had escaped from poverty pre-crisis that fell back.
} 
mixed record in this regard. Their analysis is based on two successive rounds of the Russian Longitudinal Monitoring Survey (carried out with about 3,800 households in October 1996 and November 1998 respectively). In the crisis, mean household expenditure fell by about 20 percent and poverty headcount (national definition, expenditure) rose from 22 percent to 33 percent. On the other hand, inequality narrowed: the Gini coefficient for expenditure actually fell from 0.44 to 0.42 ; from 0.48 to 0.42 for income. Interestingly, there were on average expenditure gains by the poor between 1996 and 1998, and 42 percent of the 1996 poor had escaped from poverty two years later. The apparent paradox (gains by the poor, but increasing poverty headcount) is resolved by realizing that the overall increase in headcount reflected the very large number - over a quarter - of the previously non-poor that fell into poverty. Increases in poverty rates are lower if measured in terms of income rather than expenditure, and it seems that the expenditure responses reflected excessively precautionary behavior.

\section{African crises of the 1990s}

Sizable short-run improvements in inequality were recorded in three African countries, Kenya, Uganda and Zambia, around the time that their banking crises broke in 1993-5 (Figure 2). Yet it may be unwise to jump to conclusions about the causality of such a correlation. For none of these three crises were associated with any large output dip (cf. the country entries in Caprio et al., 2005). The Uganda case relates to the decision to face up to the deep insolvency of a large state-owned bank at the center of the system. The Kenya and Zambia cases related to mismanagement and perhaps fraud at sizable banks unrelated to macroeconomic conditions. It is likely that the distributional changes that occurred in these countries during the mid-1990s were more closely related to terms of trade changes that were rather independent of the banking conditions.

These important cases highlight the possibility that banking crises can be accompanied by falling inequality. The next section examines the full set of documented banking crises to see what have been the associated movements of inequality.

\section{Broad cross-country evidence}

In this section, we look at cross-country data on Gini coefficients of income or expenditure and on the distribution-related changes in poverty. A caveat is in order. It is not implied that Gini, or indeed relative inequality in general, is the most important aspect of the welfare impact of financial crises. Indeed, as mentioned above the Gini is very far from being a useful measure of welfare in this context, not least because an uniform percentage reduction in cash income may have a much greater impact on the welfare of the poor than that of the rich. ${ }^{15}$ Instead, the purpose here is the analytical one of isolating distributional effects from the (larger) overall welfare effects which result especially from the across-the-board decline in mean income at all level of society which is typical of many crises. ${ }^{16}$

\footnotetext{
${ }^{15}$ Despite the logical difficulties involved in making interpersonal comparisons, Atkinson's index based on the perspective of an inequality-averse social welfare function, or poverty measures such as the FGT class can be used to address the wider welfare questions.

${ }^{16}$ The common presumption that poverty headcount invariably increases around crises is also contradicted by Povcal data (cf. Figure 3, where the dates and cases correspond to those used in Table 3b). In most
} 
However one wants to approach the issue, the raw material will be the change in real income and expenditure of different income deciles, and for this one must consult the evidence of household surveys.

For a wide cross-country analysis of movements in poverty and inequality around the time of financial crises, the Povcal database is an inevitable choice. It contains such data for 95 countries and between one and 14 different years (an average of 4-5 observations for each country). Matching this with the Caprio-Klingebiel banking crisis data set giving details on 180 crises in 149 countries (including advanced economies) offers the prospect of assessing correlations in a useful way (Caprio et al. 2005).

\section{Timing}

Yet we have to be careful. Timing of the crises is one of the most uncertain aspects of the crisis database, yet issues of timing are crucial to our analysis of the effects of crisis on poverty and inequality, if we are to capture what (as argued above) are potentially contrasting short-term and long-term effects.

The only systematic econometric cross-country study of which I am aware that attempts to detect the impact of banking crises on inequality is Lopez (2004). ${ }^{17}$ The goal of his paper is to explore the impact of different policy approaches on inequality and growth in the short run and in the long run. He uses a somewhat larger database, that used by Dollar and Kraay (2002) (updated), and focuses on changes in inequality over five-year intervals. Lopez's solution to the timing problem is to take non-overlapping five-year intervals and choose the latest available Gini coefficient in each interval. For banking crises (only one of his explanatory variables), he uses the number of years in the relevant five-year period for which a crisis is ongoing. ${ }^{18}$ Lopez employs the Arellano-Bond GMM econometric methodology which involves double differencing of this data, and this arguably places a premium on data accuracy. ${ }^{19}$ Interestingly, he finds that the crisis variable is highly significant, with a t-statistic of over $4 .^{20}$ Five-year periods in which

countries, however, poverty headcount is, however, on a downward medium-term trend which somewhat complicates the separate identification of the effects of shocks. The problem is illustrated in the data of Table 4, where a sharp fall in the poverty headcount in Ghana is the most dominant feature. Adjusting for the different trends in different countries uses up most of the available degrees of freedom.

${ }^{17}$ Panizza (2004) also provides some evidence, but limits himself to the Latin American cases also studied by Lustig (2000).

${ }^{18}$ Note the implicit assumption here that, if a country is not reported in the crisis database as having an ongoing crisis, then it is crisis-free for that period. However the authors of the crisis database have warned that it is an incomplete catalog of crises, and does not declare as crisis-free the countries and dates that are not mentioned.

${ }^{19}$ And also reduces the degrees of freedom because of the need to exclude countries with fewer than three observations. From 953 observations on 137 countries, the double differencing reduces the effective sample size to 194 observations on 61 countries. Further merging with the policy and growth data reduces Lopez sample further to 134 observations on 41 countries.

${ }^{20}$ His other policy variables include: initial GDP per capita, initial output gap, education (secondary enrolment), financial depth, trade openness, government consumption as share GDP, public infrastructure (telephone lines) price stability, governance (first principal component of the ICRG indicators), cyclical volatility, external imbalances, and the growth in the terms of trade. All but the last four are found to be significant in explaining changes in the Gini. The inclusion of several variables likely to be correlated with 
there are more crisis years experience a decline in inequality. The size of the effect indicated by the point estimate is not huge: a five-year long crisis is estimated to lower the log of Gini by 0.02 , equivalent at the sample mean value to moving the Gini from 0.376 to 0.368 .

Lopez's finding can be seen as broadly consistent with the Indonesian evidence, and the other cases mentioned where Gini has declined around the time of crises.

By taking the number of crisis years in a given five-year period as the crisis variable, he is implicitly focusing on short and medium-term impacts of the crisis denouement. However, this variable entails heavy reliance on the accuracy of the crisis end-dates, whereas it is known that these dates are especially uncertain, essentially because the process of resolving failed financial institutions is a long-drawn-out one. Thus, in respect of several crises, no end-point is shown despite the fact that the crisis has been fully resolved. (Lesotho is a good example: taking the lack of an end-date as an indication that the crisis shown as beginning in 1988 was still running in 2002 would be misleading.)

Furthermore, the alignment of the Gini and crisis measures is somewhat problematic, given that some of the Ginis are measured early within the five-year period and possibly before even a crisis that scores 0.6 or 0.8 on the index got under way.

These timing issues are likely to bedevil any work in this area; noting them does not detract from the useful exercise carried out by Lopez, but points to the desirability of looking further at the dynamics of the Gini around the known crisis dates.

It is worth mentioning here that another major difficulty in mechanically applying the crisis database is that many of the countries without reported crises are known to have rather dysfunctional controlled banking systems, but ones which have managed to remain solvent or nearly so.

\section{Gini coefficients before and after crises}

(a) Long-term effects

Looking first at long-term effects, it is of interest to compare Gini coefficients measured before any crisis hit, with those measured a sufficiently long interval (say ten years) after any crisis was reported as being in progress.

Because of the frequency and protracted nature of banking crises, there are relatively few datapoints in either category. Thus, confining ourselves to the data in Povcal (and excluding transition economies ${ }^{21}$ ), we obtain just 23 pre-crisis Gini observations, with a range from 0.26 to 0.63 , a mean of 0.439 and a standard deviation of 0.102 . As for "long-after" post-crisis observations, i.e. those 10 years or more after the last recorded crisis date, there are also 23 of these, ranging from 0.29 to 0.74 , with a mean of 0.476 and

banking crises - complicates the interpretation. Also note that, contrary to other results in the literature (e.g. Beck et al., 2004) financial deepening is found by Lopez to worsen inequality.

${ }^{21}$ For whom the strong, known, dynamics of increasing measured inequality will surely swamp any crisis effects. 
a standard deviation of 0.116 (Table 1 (a); Figure 4). Unfortunately, only two countries (Colombia and Madagascar) are in both sets (Colombia shows an almost unchanged Gini as between the before and after calculation at 0.59; Madagascar shows a decline from 0.49 to 0.42 ). As a result, comparison of the summary statistics must be done with some caution. However, there is no decisive support in this data for the hypothesis, discussed above, that pre-crisis Ginis would be systematically higher than post-crisis. The scatter is simply too wide, and other country and conjunctural influences swamp any systematic effects of banking crises.

If we had before and after data on numerous countries, we could take the before-after difference as an indication of the impact of the crisis, since doing so would eliminate country fixed effects. However, given that this data represents almost disjoint sets of "before any" and "long after" countries, we cannot do this (or even use country dummies). Instead, in seeking to identify the effect of crises, we need to control for other factors that affect the general level of Gini in different countries. If we can pin down a small but important set of such factors, this will allow the effect of crises to be estimated more reliably by including a $0-1$ dummy variable indicating whether each observation is a "before any" or "long after" Gini. In fact, the inequality literature does not seem to point very clearly to what these determinants might be, and clearly there is the risk of data-mining exercise. Nevertheless, an R-squared of 0.61 can be achieved, for example, in a regression of the long-term pre-or-post crisis Ginis $(\mathrm{N}=43)$ by inclusion of dummies for Latin America and Sub-Saharan Africa, average inflation rate, the Heritage Foundation index of "economic freedom" and the (log of) GNP per capita (all of which have an estimated positive effect on Gini). Even with these base-level controls, the before-or-after dummy does not contribute significantly to the fit. The point estimate is positive, implying an increase of about 0.02 in the Gini, i.e. more inequality after the crisis, but this estimate is statistically insignificant (Regression Table $1 \mathrm{a}, \mathrm{b}$ ). ${ }^{22}$

In order to detect whether alternative policy approaches influenced the long-term inequality impact of crises, we can try adding variables indicating the financial sector policies adopted around crises. Unfortunately, the overlap between this set of countries and those in Honohan-Klingebiel (2003) is slight, covering only 9 countries. However it is suggestive that the policy orientation found by $\mathrm{HK}$ to lower fiscal costs (i.e. nonaccommodating policies - no unlimited depositor guarantees or extensive capital forbearance) are also found to be associated with reductions in Gini, often significantly (Regression Table 1c). ${ }^{23}$ as between "before any" and "long after". (Of course this approach is limited by the consideration that HK looked only at crisis events, and as such neglect the potential protective role of these policies in avoiding crises.)

\footnotetext{
${ }^{22}$ Inclusion of other controls, such as measures of financial depth, legal origin, property rights protection, corruption, illiteracy or population size do not significantly alter the picture. These regressions all exclude Transition economies.

${ }^{23}$ The results shown encompass the full set of policy variables in Honohan-Klingebiel for which results can be obtained for this sample. Their variable LIQSUP is invariant in this sample, while FORBA, FORBB and $R E P C A P$ are perfectly correlated.
} 
Of course, as mentioned, factors other than financial sector policy, including the economy's ability to absorb shocks and safety net policies, are key determinants of the inequality consequences of a crisis. The equations presented remain quite underspecified.

(b) Short-term effects

However, the same database allows us a somewhat clearer look at short-term impacts. First, there are 13 cases where we have an estimate both of the immediate pre-crisis Gini (not more than three years before the onset of the crisis) and that which is observed in the immediate aftermath of the end of the crisis. These are plotted in Figure 5. We immediately see that, once more, there is no general tendency for a reduction in the Gini in this time interval. Indeed, the mean Gini increases slightly (and without statistical significance) from 0.428 to 0.437 . Sizable Gini falls are recorded for Zambia, Algeria, Yemen and Madagascar, but these are offset by increases in Nigeria, Costa Rica, Bangladesh and Nepal.

Perhaps more interesting is an even shorter time frame which looks at individual crises, as distinct from the entire country crisis history, and takes cases where a Gini estimate is available shortly (not more than 3 years) before the onset of the crisis and shortly (again not more than 3 years) after the onset. This provides a shorter interval and as such is less likely to be contaminated by secular trends. This data is available for twelve crises from eleven non-Transition countries and is shown in shown in Table 3 (panel b) and plotted in Figure 2. In this case too, there are both increases and declines in the Gini, but this time there is a small (still statistically insignificant) average decline in the Gini as predicted by the short-term hypothesis discussed above. Interestingly, there is a clear regional pattern to the increases and decreases. All but one of the increases in inequality during the crisis are in Latin America, all of the decreases are elsewhere (Africa and Asia). The small number of observations militate against worthwhile regression analysis: as illustrated in Regression Table 2, only the Africa dummy is significant.

\section{Distributional effects on poverty near crises}

A third approach to selecting and sorting the cross-country information is to move to the careful decomposition prepared by Kraay (2004) of changes in poverty between the part attributable to changes in mean income (at a constant Lorenz curve) and the part attributable to distributional shifts. Kraay has conducted this decomposition for over 200 non-overlapping intervals for which sufficient data is available, and I am very grateful to him for making this data available to me before its publication. Of these intervals, some 42 span the onset of a banking crisis recorded in the Caprio et al. database in the sense that the first year of the crisis either coincides with the start of the data interval, or is after that start date and strictly before the end date of the data interval. Note that this choice of intervals is rather different to that employed above, but is conceptually somewhat close to the short-term individual crisis calculation. Nevertheless, this approach gives us a larger set of observations, 41 of which 16 relate to transition economies.

Regression analysis of the 25 non-transition cases suggests that, even when poverty increases with a fall in overall income following crisis, the impact of distributional 
changes following the onset of crisis actually work on average in the direction of lowering poverty (though this is not statistically significant), except in Latin America. Attempts to detect whether certain country institutional characteristics or crisis characteristics (using the Honohan, 2000, classification system) influence this effect were broadly unsuccessful. Interestingly, though, the KKZ indicator of corruption was associated with favorable distributional changes: possibly suggesting that in corrupt countries the crises were associated with a loss of previous privilege by beneficiaries of corruption. These regressions have large outliers, though (notably Kenya and the Kyrgyz Republic), and the size and significance of coefficients are sensitive to the inclusion or otherwise of these outliers (Regression Table 3).

This overview of the evidence from cross-country data confirms that the short-run pattern of inequality movements around banking crises differs from country to country. Outside of Latin America, these short-term changes are more likely than not to have been favorable to distribution.

The small number of specific crises for which appropriately-timed inequality data are available and the likely high noise-to-signal ratio in the inequality data militate against successful multivariate statistical analysis to control for independent causal factors influencing inequality movements around the time of the crisis.

\section{Policy conclusions}

Available cross-country data on movements in inequality around the time of banking crises do not send very clear messages on the factors that influence whether crises will be associated with more or less inequality. This contrasts with recent evidence that financial deepening is a causal factor in reducing poverty (Honohan, 2004a and b, Beck DemirgüçKunt and Levine, 2004).

This is not the place to discuss general policy measures to reduce the frequency and scale of systemic banking crises and to improve containment and resolution of those that occur. Banking policies that improve the soundness of the banking system, thereby reducing the frequency of crises, are likely to be associated with less inequality and faster reduction in poverty in the long run.

Nevertheless, the discussion does suggest some general policy recommendations. For one thing, the way in which withdrawals of wealthy and well-informed depositors are often financed by central bank liquidity lending needs careful consideration at the containment stage of crises: all too often national foreign exchange reserves are deeply eroded in this process without any realistic hope of such lending preventing the need for bank intervention and indeed devaluation. These policies may occasionally be an appropriate tactic to head off an irrational speculative attack on a fundamentally sound banking system, but all too often are employed in circumstances where they are unlikely to succeed. Then, while they may buy a postponement of the crisis, this will be at the cost of an adverse distributional impact. 
More generally, accommodating policies, including an overly generous depositor safety net, risk worsening the ultimate fiscal costs, thereby limiting the scope for other safety net policies of more relevance to the poor.

The fact that income inequality has frequently narrowed at times of banking crisis does not remove the need for policy action to minimize and alleviate the jump in poverty which often accompanies these events. To a large extent this relates to safety net and macroeconomic management policies not specific to the financial sector and which have been extensively discussed in the literature (Ferreira et al. 1999, Manuelyan-Atinc and Walton, 1998). 
Table 1: LSMS Surveys with Financial Sector Information and Dates of Crises

\begin{tabular}{lcc}
\hline & Date of LSMS & Date of Crisis \\
\hline Albania & 2002 & $1992-96$ \\
Armenia & 1996 & $1994-96$ \\
Bosnia \& Herzegovina & 2001 & $1992-$ \\
Brazil & $1996 / 97$ & $1994-99$ \\
Bulgaria & 2001 & $1996-97$ \\
China & $1995 \& 1997$ & 1990 s- \\
Côte d'Ivoire & 1988 & $1988-91$ \\
Ecuador & 1998 & $1998-2001$ \\
Ghana & $1998 / 99$ & $1982-89$ \\
Guatemala & 2000 & 1990 s \\
Guyana & $1992 / 93$ & \\
India & $1997 / 98$ & $1993-$ \\
Kosovo & 2000 & \\
Jamaica & 1997 & 1994 \\
Kazakhstan & 1996 & \\
Kyrgyz Republic & 1998 & 1990 s \\
Morocco & 1991 & 1988 \\
Nepal & 1996 & Early 1980 s \\
Nicaragua & $1998-99$ & 1980 s-96 \\
Pakistan & 1991 & $1988-89$ \\
Panama & 1997 & $1983-90$ \\
Peru & 1994 & $1990-96$ \\
Romania & $1994 / 95$ & 1995 \\
Russia & 1992 & $1996-$ \\
South Africa & 1993 & \\
Tajikistan & 1999 & \\
Vietnam & $1997-98$ & \\
\hline Note: Itaized &
\end{tabular}

Note: Italicized dates denote non-systemic crisis.

Source for crisis dates: Caprio et al. (2005); for LSMS Honohan (2004c).

Table 2: Mexico: Alternative estimates of Household Inequality Gini 1992-1998.

\begin{tabular}{llrrrr}
\hline Author & Concept & 1992 & 1994 & 1996 & 1998 \\
\hline Luxembourg Income Study & Net Income & 54.5 & 55.3 & 53.4 & 54.8 \\
Szekely and Hilgert (1999) & Net Income & 53.4 & 53.6 & 52.8 & \\
Lopez-Acevedo and Salinas (2000) & Total Income & 53.1 & 53.4 & 51.9 & \\
Baldacci et al (2002) & Income & 54.1 & 54.2 & 51.6 & \\
Baldacci et al (2002) & Consumption & 52.7 & 51.6 & 50.2 & \\
Deininger and Squire (2004) & Gross income & 60.7 & 56.4 & 54.9 & 55.4 \\
World Development Indicators/Povcal Expenditure & 50.3 & $53.7^{\text {a }}$ & 51.9 & 53.1 \\
\hline
\end{tabular}
${ }^{\mathrm{a}} 1995$

Source: WIDER World Income Inequality Database (WIID), Baldacci et al. (2002), Lopez-Acevedo and Salinas (2000), Povcal (accessed August 2004). 


\section{Table 3: Gini Coefficients before and after Banking Crises}

(a) Before, after end of, and long after end of all of the crises in each country

\begin{tabular}{|c|c|c|c|c|c|c|c|}
\hline \multirow[b]{2}{*}{ DZA } & \multirow[b]{2}{*}{ Algeria } & \multicolumn{2}{|c|}{ Before any } & \multicolumn{2}{|c|}{ Soon after end } & \multicolumn{2}{|c|}{ Long after end } \\
\hline & & 40.1 & 1988 & 35.3 & 1995 & & \\
\hline BGD & Bangladesh & 25.9 & 1983 & 31.8 & 2000 & & \\
\hline BWA & Botswana & & & & & 60.4 & 1989 \\
\hline BRA & Brazil & 59.5 & 1985 & 59.2 & 2001 & & \\
\hline BDI & Burundi & 33.3 & 1992 & & & & \\
\hline CHL & Chile & & & & & 56.3 & 1997 \\
\hline $\mathrm{COL}$ & Colombia & 59.1 & 1980 & 59.3 & 1998 & 59.3 & 1998 \\
\hline CRI & Costa Rica & 42.5 & 1990 & 47.9 & 1998 & & \\
\hline CIV & Côte d'Ivoire & 40.1 & 1986 & 36.8 & 1994 & & \\
\hline DOM & Dominican Republic & 49.2 & 1995 & & & & \\
\hline EGY & Egypt & & & & & 33.5 & 1997 \\
\hline SLV & El Salvador & & & & & 53.3 & 2000 \\
\hline ETH & Ethiopia & & & & & 34.1 & 1992 \\
\hline GMB & Gambia, The & & & & & 49 & 1995 \\
\hline GTM & Guatemala & & & & & 58.4 & 1993 \\
\hline HND & Honduras & & & & & 56 & 1993 \\
\hline IND & India & & & & & 32.5 & 1990 \\
\hline IDN & Indonesia & 33.7 & 1990 & & & & \\
\hline IRN & Iran & & & & & 44.5 & 1992 \\
\hline JAM & Jamaica & 38.9 & 1990 & & & & \\
\hline JOR & Jordan & & & & & 38.6 & 1992 \\
\hline LSO & Lesotho & & & & & 59 & 1992 \\
\hline MDG & Madagascar & 46.8 & 1980 & 46.1 & 1993 & 42.3 & 2000 \\
\hline MYS & Malaysia & 48.6 & 1984 & & & & \\
\hline MAR & Morocco & & & & & 39.5 & 1998 \\
\hline NAM & Namibia & & & & & 74.3 & 1993 \\
\hline NPL & Nepal & 31.7 & 1984 & 36.7 & 1995 & & \\
\hline NGA & Nigeria & 38.7 & 1985 & 50.6 & 1996 & & \\
\hline PAK & Pakistan & & & & & 32.2 & 1993 \\
\hline PAN & Panama & & & & & 56.6 & 2000 \\
\hline PGY & Paraguay & 39.7 & 1990 & & & & \\
\hline PER & Peru & & & & & 49.8 & 2000 \\
\hline RWA & Rwanda & & & & & 28.9 & 1984 \\
\hline SLE & Sierra Leone & 62.9 & 1989 & & & & \\
\hline ZAF & South Africa & & & & & 57.8 & 1996 \\
\hline LKA & Sri Lanka & 32.5 & 1985 & 34.4 & 1995 & & \\
\hline LCA & St Lucia & & & & & 42.6 & 1995 \\
\hline SWZ & Swaziland & 60.7 & 1994 & & & & \\
\hline THA & Thailand & 45.2 & 1981 & & & & \\
\hline TTO & Trinidad & & & & & 41.4 & 1990 \\
\hline TUN & Tunisia & & & & & 41.5 & 1993 \\
\hline UGA & Uganda & 43.8 & 1990 & 43.1 & 1999 & & \\
\hline YEM & Yemen & 39.4 & 1992 & 33.4 & 1998 & & \\
\hline ZMB & Zambia & 56.9 & 1992 & 51.2 & 1997 & & \\
\hline ZWE & Zimbabwe & 39.4 & 1990 & & & & \\
\hline
\end{tabular}


(b) Just before and just after onset of particular event

\begin{tabular}{llrrrr}
\hline & & \multicolumn{2}{c}{ Before } & \multicolumn{2}{c}{ Just after onset } \\
\hline ARG & Argentina, 1995 & 45.4 & 1992 & 48.6 & 1996 \\
BRA & Brazil, 1994 & 59.8 & 1993 & 61.5 & 1995 \\
ARG & Argentina, 1989 & 44.5 & 1986 & 45.4 & 1992 \\
MEX & Mexico, 1994 & 50.3 & 1992 & 51.9 & 1996 \\
PHL & Philippines, 1998 & 46.2 & 1997 & 46.1 & 2000 \\
KEN & Kenya, 1993 & 57.5 & 1992 & 44.5 & 1994 \\
THA & Thailand, 1997 & 43.4 & 1997 & 41.4 & 1998 \\
ZMB & Zambia, 1995 & 52.6 & 1993 & 49.8 & 1996 \\
CRI & Costa Rica, 1994 & 46.3 & 1993 & 47.1 & 1996 \\
UGA & Uganda, 1994 & 43.2 & 1992 & 37.4 & 1996 \\
JAM & Jamaica, 1994 & 35.7 & 1993 & 36.4 & 1996 \\
BGD & Bangladesh, 1980s & 26.9 & 1985 & 28.8 & 1988 \\
\hline & Mean & 46.0 & 45.1 & \\
& Standard deviation & 8.9 & \multicolumn{4}{c}{8.5} \\
\hline
\end{tabular}

(c) Just before and just after onset of particular event - Transition economies

\begin{tabular}{llrrrr}
\hline & & \multicolumn{2}{c}{ Before } & \multicolumn{2}{c}{ Just after onset } \\
\hline BGR & Bulgaria, 1996 & 31.1 & 1995 & 26.4 & 1997 \\
CZE & Czech Republic, 1989 & 19.4 & 1988 & 26.5 & 1993 \\
EST & Estonia, 1992 & 23.0 & 1988 & 39.5 & 1993 \\
HUN & Hungary, 1991 & 25.0 & 1989 & 27.9 & 1993 \\
LVA & Latvia, 1995 & 27.0 & 1993 & 31.6 & 1996 \\
LTU & Lithuania, 1995 & 37.2 & 1994 & 32.4 & 1996 \\
POL & Poland, 1992 & 26.9 & 1989 & 32.7 & 1996 \\
ROM & Romania, 1990 & 23.3 & 1989 & 25.5 & 1992 \\
RUS & Russia, 1995 & 46.2 & 1996 & 45.6 & 2000 \\
RUS & Russia, 1998 & 48.3 & 1993 & 46.2 & 1996 \\
SVK & Slovakia, 1991 & 19.5 & 1988 & 19.5 & 1992 \\
UKR & Ukraine, 1997 & 33.2 & 1996 & 29.0 & 1999 \\
\hline & Mean & 30.0 & & 31.9 & \\
& Standard deviation & 9.6 & & 8.1 & \\
\hline
\end{tabular}

Note: Crisis dates are drawn from Caprio et al. 2004. For panel (a), in respect of each country in the Povcal database, other than Transition economies, Gini coefficients were extracted where available for dates (i) before any crisis hit (within 10 years); (ii) soon after the end of all crises (within 5 years); (iii) long after the end of all crises (at least 10 years). Ginis falling into this category were averaged and entered into the table together with the date to which they refer (where the Ginis are averaged over several years, the mean date is shown). For panel (b), in respect of each crisis, again excluding Transition economies, Gini coefficients were extracted where available for dates both just before and just after the onset of the crisis (within 3 years in each case). Panel (c) repeats the exercise of panel (b) for Transition economies. Gini coefficients are expressed throughout as percentages. 


\section{Table 4: Poverty and Banking Crises}

This table shows changes in absolute poverty (increase in the fraction of the population on less than the international $\$ 1$ a day benchmark) distinguishing between the parts attributable to mean income changes to distributional shifts in intervals for which data is available and which span the start of a banking crisis

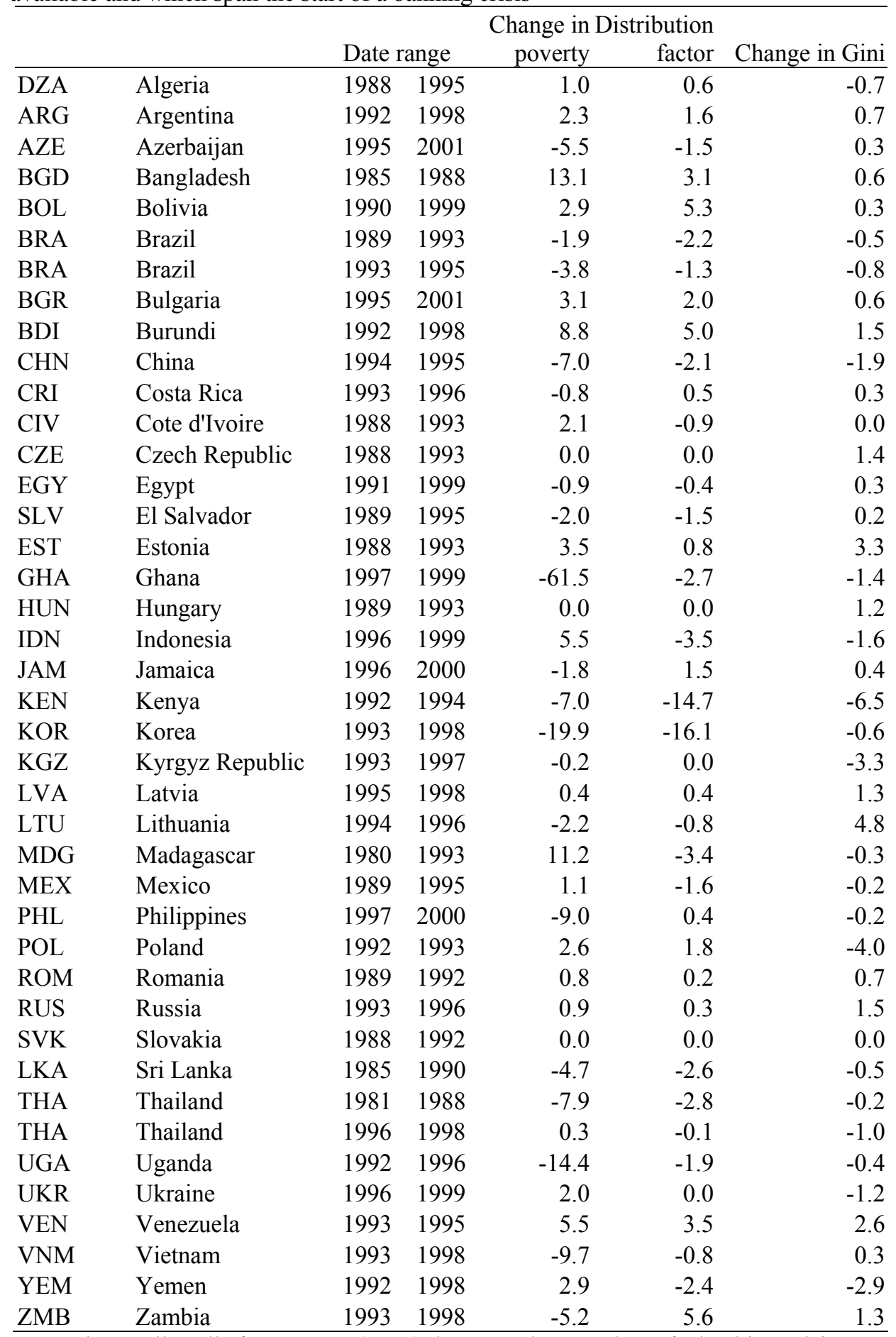

Note: Shows all spells from Kraay (2004) that span the start date of a banking crisis shown in Caprio et al. (2004). Distribution factor the change in poverty (percentage points) attributable to actual changes in Lorenz curve, holding mean constant. 
Regression Table 1(a): Long-term relation between crises and Gini Dependent variable: Gini coefficient (series of Table 3a)

\begin{tabular}{lrrrrrrrrrr}
\hline & \multirow{2}{*}{ Equation: } & \multicolumn{2}{c}{1. A } & \multicolumn{2}{c}{$1 . \mathrm{B}$} & \multicolumn{2}{c}{ 1.C } & \multicolumn{2}{c}{ 1.D } & \multicolumn{2}{c}{ 1.E } \\
& Coeff. & t-Stat & Coeff. & t-Stat & Coeff. & t-Stat & Coeff. & t-Stat & Coeff. & t-Stat \\
\hline \hline Constant & 5.35 & 0.6 & 10.3 & $* * 6.6$ & 7.5 & 0.9 & 14.4 & 1.8 & 13.3 & 1.6 \\
Inflation & 0.081 & 1.8 & 0.080 & 1.8 & 0.101 & $* 2.2$ & & & & \\
Institutions (Economic freedom) & 10.1 & $* * 3.6$ & 9.4 & $* * 3.3$ & 9.6 & $* * 3.5$ & 8.2 & $* * 2.9$ & 8.1 & $* * 2.9$ \\
Sub-Saharan Africa & 14.9 & $* * 4.0$ & 11.8 & $* * 3.8$ & 11.8 & $* * 3.8$ & 12.4 & $* * 3.9$ & 12.5 & $* * 3.9$ \\
Latin America & 12.0 & $* * 2.9$ & 9.3 & $* 2.5$ & 8.4 & $* 2.3$ & 11.5 & $* * 3.2$ & 11.3 & $* * 3.1$ \\
Middle East and North Africa & 7.0 & 1.5 & & & & & & & & \\
End of crisis dummy & & & & & 4.1 & 1.5 & & & 2.4 & 0.9 \\
Countries excluded & Trans & & Trans & & Trans & & Trans & & Trans & \\
\hline R-squared / NOBS & 0.504 & 43 & 0.473 & 43 & 0.504 & 43 & 0.430 & 43 & 0.442 & 43 \\
Adjusted R-squared & 0.437 & & 0.418 & & 0.437 & & 0.387 & & 0.384 & \\
S.E. of regression & 8.4 & & 8.6 & & 8.43 & & 8.81 & & 8.8 & \\
Log likelihood & -149.5 & & -150.8 & & -149.5 & & -152.5 & & -152.0 & \\
\hline \hline
\end{tabular}

Regression Table 1(b): Long-term relation between crises and Gini Dependent variable: Gini coefficient (series of Table 3a)

\begin{tabular}{|c|c|c|c|c|c|c|c|c|c|c|}
\hline \multirow[t]{2}{*}{ Equation: } & \multicolumn{2}{|c|}{$\overline{1 . F}$} & \multicolumn{2}{|c|}{ 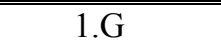 } & \multicolumn{2}{|c|}{ 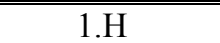 } & \multicolumn{2}{|c|}{ 1.I } & \multicolumn{2}{|c|}{ 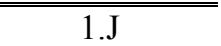 } \\
\hline & Coeff. & t-Stat & Coeff. & t-Stat & Coeff. & t-Stat & Coeff. & t-Stat & Coeff. & t-Stat \\
\hline Constant & $\overline{-35.2}$ & *2.4 & -34.1 & $\overline{* 2.3}$ & 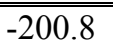 & $\overline{0.3}$ & -18.8 & $\overline{1.3}$ & 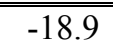 & $\overline{1.3}$ \\
\hline Inflation & 0.080 & 2.0 & 0.092 & $* 2.2$ & 0.092 & 2.0 & & & & \\
\hline Institutions (Economic freedom) & 6.1 & $* 2.3$ & 6.4 & $* 2.4$ & 6.3 & $* 2.3$ & & & & \\
\hline Sub-Saharan Africa & 16.0 & $* * 5.4$ & 15.8 & $* * 5.3$ & 15.7 & $* * 5.1$ & 15.5 & $* * 5.0$ & 9.8 & $* * 4.9$ \\
\hline Latin America & 6.1 & $* 2.3$ & 7.1 & $* 2.1$ & 6.8 & 2.0 & 9.8 & $* * 3.0$ & 15.5 & $* * 3.0$ \\
\hline GNI per cap (PPP, log) & 6.7 & $* * 3.6$ & 6.3 & $* * 3.3$ & 6.3 & $* * 3.3$ & 6.9 & $* * 3.9$ & 7.0 & $* * 3.7$ \\
\hline End of crisis dummy & & & 2.3 & 1.0 & 1.8 & 0.6 & & & -0.2 & 0.1 \\
\hline Date & & & & & 0.084 & 0.3 & & & & \\
\hline Countries excluded & Trans & & Trans & & Trans & & Trans & & Trans & \\
\hline R-squared / NOBS & 0.610 & 43 & 0.620 & 43 & 0.621 & 43 & 0.486 & 45 & 0.486 & 45 \\
\hline Adjusted R-squared & 0.557 & & 0.556 & & 0.545 & & 0.448 & & 0.434 & \\
\hline S.E. of regression & 7.5 & & 7.5 & & 7.6 & & 8.2 & & 8.3 & \\
\hline Log likelihood & -144.3 & & -143.8 & & -143.7 & & -156.4 & & -156.4 & \\
\hline
\end{tabular}


Regression Table 1(c): Long-term relation between crises and Gini

Dependent variable: Gini coefficient (series of Table 3a)

\begin{tabular}{|c|c|c|c|c|c|c|c|c|c|c|}
\hline \multirow[t]{2}{*}{ Equation: } & \multicolumn{2}{|c|}{ 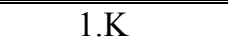 } & \multicolumn{2}{|c|}{ 1.L } & \multicolumn{2}{|c|}{ 1.M } & \multicolumn{2}{|c|}{$1 . \mathrm{N}$} & \multicolumn{2}{|c|}{$1 . \mathrm{O}$} \\
\hline & Coeff. & t-Stat & Coeff. & t-Stat & Coeff. & t-Stat & Coeff. & $\mathrm{t}-$ Stat & Coeff. & t-Stat \\
\hline Constant & -95.8 & $* * 9.2$ & -100.8 & **7.6 & -105.6 & $* * 8.0$ & -90.0 & **5.2 & -88.1 & **3.0 \\
\hline \multicolumn{11}{|l|}{ Inflation } \\
\hline \multicolumn{11}{|l|}{ Institutions (Economic freedom) } \\
\hline Sub-Saharan Africa & 18.4 & $* * 9.5$ & 19.6 & $* * 8.4$ & 20.6 & $* * 9.0$ & 17.8 & $* * 5.8$ & 17.9 & $* * 3.4$ \\
\hline Latin America & 13.7 & $* * 13.4$ & 12.8 & $* * 10.0$ & 12.9 & $* * 9.0$ & 12.1 & $* * 6.9$ & 11.2 & $* * 4.0$ \\
\hline GNI per cap (PPP, log) & 15.9 & $* * 12.5$ & 16.6 & $* * 10.7$ & 17.2 & $* * 11.0$ & 15.4 & $* * 7.5$ & 15.1 & $* * 4.3$ \\
\hline End of crisis dummy & & & 1.8 & 1.2 & & & & & & \\
\hline \multicolumn{11}{|l|}{ Date } \\
\hline Policy & -1.9 & $* 2.2$ & & & & & & & & \\
\hline Policy $\mathrm{x}$ End of crisis dummy & 7.7 & $* * 6.1$ & 5.1 & $* 2.2$ & 7.1 & $* * 4.1$ & 4.2 & $* 2.8$ & 2.2 & 0.6 \\
\hline Which policy & GUAR & & GUAR & & GUAR & & FORB1 & & $P D R P$ & \\
\hline Countries excluded & Trans & & Trans & & Trans & & Trans & & Trans & \\
\hline R-squared / NOBS & 0.997 & 9 & 0.995 & 9 & 0.993 & 9 & 0.986 & 9 & 0.964 & \\
\hline Adjusted R-squared & 0.992 & & 0.986 & & 0.985 & & 973 & & 0.928 & \\
\hline S.E. of regression & 1.0 & & 1.3 & & 1.4 & & 1.8 & & 3.0 & \\
\hline Log likelihood & -7.6 & & -10.2 & & -11.9 & & -14.6 & & -19.0 & \\
\hline
\end{tabular}

** and * indicate significance at the $1 \%$ and $5 \%$ levels, respectively.

The dependent variable is the "long before" and "long after" Gini coefficients reported in Table 3(a)

Inflation rate is the mean of CPI inflation for the 1990s (Source International Financial Statistics)

Institutional variable is the Heritage Foundation index of overall economic freedom - average of $1995-99$ figures subtracted from 6. GNI per capita at PPP is from World Development Indicators. Policy variables are as defined in Honohan and Klingebiel (2003). GUAR takes the value 1 if there was blanket government guarantee of deposits; FORBA indicates capital forbearance; PDRP indicates existence of a debtor relief program.

Countries excluded: all transition economies.

Regression Table 2: Short-term crisis-Gini links

Dependent variable: Change in Gini between just before and just after onset of crisis (series of Table $3 \mathrm{~b}$ )

\begin{tabular}{|c|c|c|c|c|c|c|c|c|c|}
\hline \multirow{2}{*}{\multicolumn{2}{|c|}{ Equation: }} & \multicolumn{2}{|c|}{ 2.A } & \multicolumn{2}{|c|}{$2 . \mathrm{B}$} & \multicolumn{2}{|c|}{$2 . \mathrm{C}$} & \multicolumn{2}{|c|}{ 2.D } \\
\hline & & Coeff. & t-Stat & Coeff. & t-Stat & Coeff. & t-Stat & Coeff. & t-Stat \\
\hline Constant & & 0.97 & 1.1 & $\begin{array}{c}-0.07 \\
\end{array}$ & 0.0 & 1.62 & 0.7 & -1.06 & 0.2 \\
\hline Africa & & -8.17 & $* * 4.6$ & -7.13 & $* * 3.2$ & -8.27 & $* * 4.3$ & -8.10 & $* * 4.3$ \\
\hline Latin America & & & & 1.55 & 0.8 & & & & \\
\hline Institutions (Corrupt) & & & & & & -0.134 & 0.3 & 0.045 & 0.4 \\
\hline Initial Gini & & & & & & & & & \\
\hline Countries excluded & & Non & & Non & & & None & $\mathrm{Nol}$ & \\
\hline R-squared / NOBS & & 0.676 & 12 & 0.698 & 12 & 0.679 & 12 & 0.683 & 12 \\
\hline Adjusted R-squared & & 0.644 & & 0.631 & & 0.608 & & 0.613 & \\
\hline S.E. of regression & & 2.7 & & 2.7 & & 2.8 & & 2.8 & \\
\hline Log likelihood & & -27.8 & & -27.3 & & -27.7 & & -27.6 & \\
\hline
\end{tabular}

$* *$ and $*$ indicate significance at the $1 \%$ and $5 \%$ levels, respectively. 
Regression Table 3: Distribution effect on poverty near crises

Dependent variable: Change in poverty headcount at unchanged mean income (series of Table 4)

\begin{tabular}{|c|c|c|c|c|c|c|c|c|c|c|c|}
\hline & \multirow[t]{2}{*}{ Equation: } & \multicolumn{2}{|c|}{ 3.A } & \multicolumn{2}{|c|}{ 3.B } & \multicolumn{2}{|c|}{$3 . \mathrm{C}$} & \multicolumn{2}{|c|}{ 3.D } & \multicolumn{2}{|c|}{$3 . \mathrm{E}$} \\
\hline & & Coeff. & t-Stat & Coeff. & t-Stat & Coeff. & t-Stat & Coeff. & t-Stat & Coeff. & $\mathrm{t}$-Stat \\
\hline$\overline{\text { Constant }}$ & & $\overline{-20.80}$ & $\overline{0.5}$ & $\overline{0.56}$ & $\overline{0.7}$ & 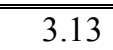 & $* 2.5$ & 3.03 & $* 2.5$ & 4.98 & 1.9 \\
\hline Latin America & & 2.26 & 1.3 & 1.66 & 1.7 & 2.27 & $* 2.1$ & 2.46 & $* 2.4$ & 2.80 & $* 2.2$ \\
\hline Transition & & -0.01 & 0.1 & 0.132 & 0.2 & & & & & & \\
\hline Institutions (Corrupt) & & -0.102 & 0.4 & -0.244 & 1.6 & -0.839 & $* * 3.1$ & -0.901 & $* * 3.4$ & -0.73 & $* * 2.4$ \\
\hline Type of crisis (Micro) & & & & & & & & 1.91 & 1.5 & & \\
\hline Initial Gini & & & & & & & & & & -0.06 & 0.8 \\
\hline Countries excluded & & None & & $K E N$, & & Trans, & KEN & Trans, & KEN & Trans, & KEN \\
\hline R-squared / NOBS & & 0.046 & 41 & 0.119 & 39 & 0.350 & 24 & 0.417 & 24 & 0.371 & 24 \\
\hline Adjusted R-squared & & -0.031 & & 0.044 & & 0.288 & & 0.329 & & 0.277 & \\
\hline S.E. of regression & & 4.1 & & 2.2 & & 2.3 & & 2.3 & & 2.4 & \\
\hline Log likelihood & & 75.0 & & 95.3 & & 57.7 & & 59.0 & & 58.1 & \\
\hline
\end{tabular}

** and * indicate significance at the $1 \%$ and $5 \%$ levels, respectively. 


\section{References}

Baldacci, Emanuele, Luiz de Melo, and Gabriela Inchauste, 2002, "Financial Crises, Poverty, and Income Distribution,” International Monetary Fund Working Paper No. 02/04, January.

Barber, Charles Victor and James Schweithelm. 2002 Trial By Fire: Forest Fires and Forestry Policy in Indonesia's Era of Crisis and Reform. (Washington, DC: World Resources Institute).

Beck, Thorsten, Aslı Demirgüç-Kunt and Ross Levine. 2004. "Finance and Poverty: Cross-Country Evidence.” World Bank Policy Research Working Paper 3338.

Behrman, Jere R., Nancy Birdsall and Miguel Székely. 2001. "Pobreza, Desigualdad, y Liberalización Comercial y Financiera en América Latina." Inter-American Development Bank Working Paper 449. http://www.iadb.org/res/publications/pubfiles/pubWP-449.pdf

Behrman, Jere R., Anil B. Deolalikar and Pranee Tinakorn. 2000. "The Effects of the Thai Economic Crisis and of Thai Labor Market Policies on Labor Market Outcomes" Thailand Development Research Institute.

Cameron, Lisa A. 2000. "The Impact of the Indonesian Financial Crisis on Children: Data from 100 Villages Survey.” World Bank Working Paper No. 2799.

Caprio, Gerard, Daniela Klingebiel, Luc Laeven, and Guillermo Noguera. 2005.

"Banking Crisis Database" in Patrick Honohan and Luc Laeven, eds. Systemic Financial Distress: Containment and Resolution (New York: Cambridge University Press).

Deaton, Angus. 1997. The Analysis of Household Surveys. Johns Hopkins University Press, Baltimore, MD.

Diwan, Ishac. 2001. "Debt as Sweat: Labor, Financial Crises, and the Globalization of Capital” mimeo. World Bank http://www-unix.oit.umass.edu/ gepstein/econ721/Readings/diwan.DOC

Dollar, David and Aart Kraay. 2002. "Growth is Good for the Poor." Journal of Economic Growth 7: 195-225.

Frankenberg, Elizabeth, Duncan Thomas and Kathleen Beegle (FTB). 1999. "The Real Costs of Indonesia's Economic Crisis: Preliminary Findings from the Indonesia Family Life Surveys", RAND Corporation Labor and Population Program Working Paper 99-04 (DRU-2064-NIA/NICHD).

Ferreira, Francisco, Giovanna Prennushi, and Martin Ravallion, 1999, "Protecting the Poor from Macroeconomic Shocks: An Agenda for Action in a Crisis and Beyond," World Bank Working Paper No. 2160, August. 
Fields, Gary S. and Maria Laura Sanchez Puerta. 2004. "Earnings Mobility in Urban Argentina: Who Gains When the Economy Grows and Who Loses When the Economy Declines?" Cornell University, mimeo.

Friedman, Jed and James Levinsohn, 1999. “The Distributional Impacts of Indonesia's Financial Crisis on Household Welfare: A 'Rapid Response' Methodology”. World Bank Economic Review. 16(3), 397-423.

Halac, Marina and Sergio Schmukler. 2004. "Distributional Effects of Crises: The Financial Channel”. Economia 5(1): 1-67. (Earlier version was World Bank Policy Research Working Paper 3173).

Honohan, Patrick. 2000. "Banking System Failures in Developing and Transition Countries: Diagnosis and Prediction.” Economic Notes 29(1): 83-109.

Honohan, Patrick. 2004a. "Financial Development, Growth and Poverty: How Close Are the Links?" in Charles Goodhart, ed. Financial Development and Economic Growth: Explaining the Links (London: Palgrave), 1-37.

Honohan, Patrick. 2004b. Financial Sector Policy and the Poor: Selected Issues and Evidence (Washington DC: The World Bank).

Honohan, Patrick. 2004c. "Measuring Microfinance Access: Building on Existing CrossCountry Data" Prepared for the UNDP, World Bank and IMF Workshop Data on the Access of Poor and Low Income People to Financial Services Washington, DC, October 26, 2004. http://www1.worldbank.org/finance/assets/images/Honohan_Paper_2004.pdf

Inder, Brett. 2004. "Economic Growth and Contraction and Their Impact on the Poor." Monash University Working Paper.

http://www.buseco.monash.edu.au/depts/ebs/pubs/wpapers/2004/wp3-04.pdf

Kraay, Aart. 2004. "When Is Growth Pro-Poor? Evidence from a Panel of Countries." IMF Working Paper 04/47.

Levinsohn, James, Stephen Berry and Jed Friedman. 1999. "Impacts of the Indonesian Economic Crisis: Price Changes and the Poor.” NBER Working Paper 7194.

Lokshin, Michael and Martin Ravallion. 2000. “Welfare Impacts of Russia's 1998 Financial Crisis and the Response of the Public Safety Net." Economics of Transition 8(2): 269-295.

Lustig, Nora. 2000. "Crises and the Poor: Socially Responsible Macroeconomics." mimeo. Economia 1(1): 1-30. (Earlier version: http://www.iadb.org/sds/doc/POV\%2D108.pdf)

Lopez-Acevedo, Gladys and Angel Salinas. 2000. "How Mexico's Financial Crisis Affected Income Distribution." World Bank Policy Research Working Paper 2406. http://econ.worldbank.org/docs/1161.pdf 
Manuelyan Atinc, Tamar, and Michael Walton. 1998, "Social Consequences of the East Asian Financial Crisis," mimeo, World Bank.

http://www.worldbank.org/eapsocial/library/socconsq/eacrisis1.pdf

Morley, Samuel A., Roberto Machado and Stefano Pettinato. 1999. "Indexes of Structural Reform in Latin America" UN Economic Commission for Latin America Economic Reforms Series, No. 12.

http://www.eclac.cl/cgi-bin/getProd.asp?xml=/publicaciones/xml/5/4275/P4275.xml\&xsl=/de/tpl-i/p9f.xsl\&base=/tpl/top-bottom.xslt\#

Panizza, Ugo. 2004. “Discussion of Halac and Schmukler.” Economia 5(1): 57-63.

Patten, Richard H., Rosengard, Jay K., \& Johnston, Don E., Jr. 2001. "Microfinance Success amidst Macroeconomic Failure: The Experience of Bank Rakyat Indonesia during the East Asian Crisis." World Development 29(6), 1057-1069.

Ravallion, Martin. 2001. "Growth, Inequality and Poverty: Looking Beyond Averages", World Development 29(11): 1803-15.

Robilliard, Anne-Sophie, François Bourguignon and Sherman Robinson. 2002. "Examining the Social Impact of the Indonesian Financial Crisis using a Micro-Macro Model." Presented to the 2003 ABCDE-Europe conference. World Bank, mimeo. http://wbln0018.worldbank.org/eurvp/web.nsf/Pages/Paper+by+Robillliard/\$File/ROBILLIARD.PDF

Strauss, John, Kathleen Beegle, Agus Dwiyantom Yulia Herawati, Daan Pattinasarany, Elan Satriawan, Bondan Sikoki, Sukamdi and Firman Witoelar. 2004. Indonesian Living Standards: Before and After the Financial Crisis. (Singapore: Institute of Southeast Asian Studies).

Suryahadi, Asep, Sudarno Sumarto, Yusuf Suharso and Lant Pritchett. 2000. "The Evolution of Poverty during the Crisis in Indonesia, 1996 to 1999”. World Bank Policy Research Working Paper 2435.

Suryahadi, Asep, Sudarno Sumarto and Lant Pritchett. 2003. The Evolution of Poverty during the Crisis in Indonesia. SMERU Research Institute, Djarkarta. mimeo.

Thomas, Duncan and Elizabeth Frankenberg. 2005. "Household Responses to the Financial Crisis in Indonesia: Longitudinal Evidence on Budgets and Living Arrangements." in Ann Harrison, ed. Globalization and Poverty NBER Forthcoming.

Vogelgesang, Ulrike. 2003. "Microfinance in Times of Crisis: The Effects of Competition, Rising Indebtedness, and Economic Crisis on Repayment Behavior." World Development 31(12) 2085-2114.

WIDER. 2004. World Income Inequality Database (WIID). Helsinki: UNU World Institute of Development Economics Research. http://www.wider.unu.edu/wiid/wiid.htm 
Figure 1: Mexico: Alternative estimates of Gini coefficient in the early-mid 1990s. (Source: Table 3)

Mexico: Alternative Gini estimates

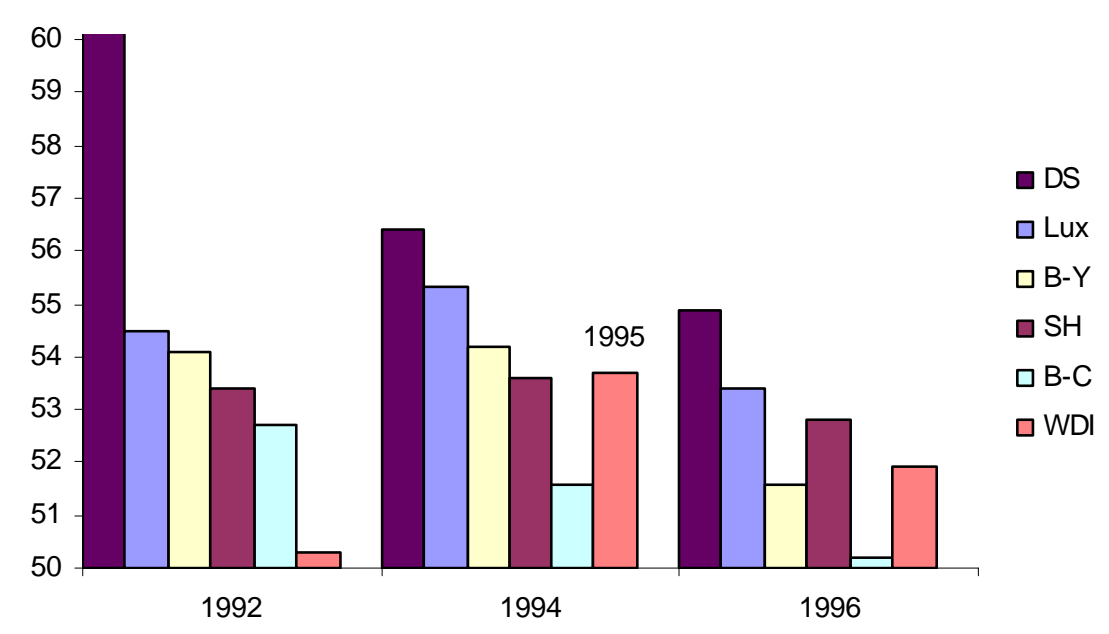


Figure 2: Gini coefficients in three African counteies duirng the 1990s (Source: Povcal)

Kenya: Gini estimates

Around the crisis of 1994-6

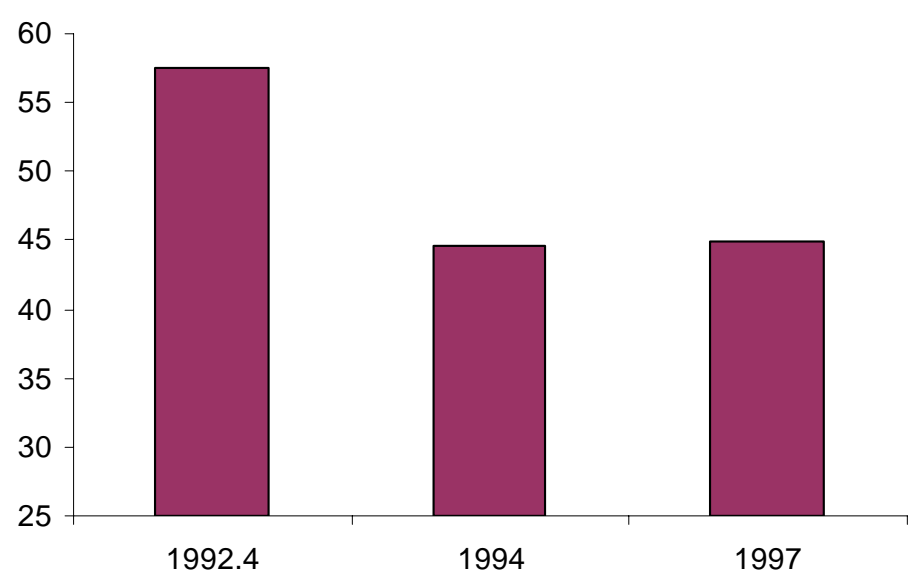

Uganda: Gini estimates

Around the crisis of 1994-6

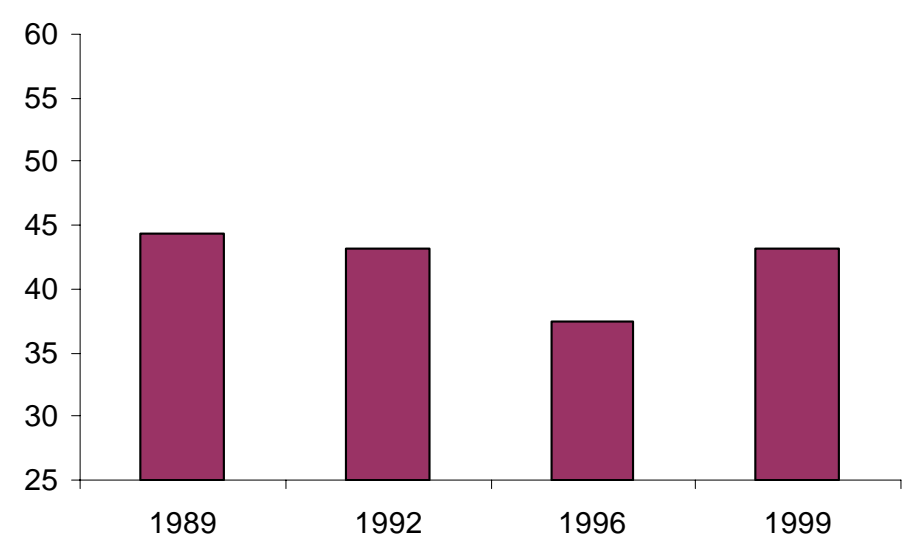

Zambia: Gini estimates

Around the crisis of 1995

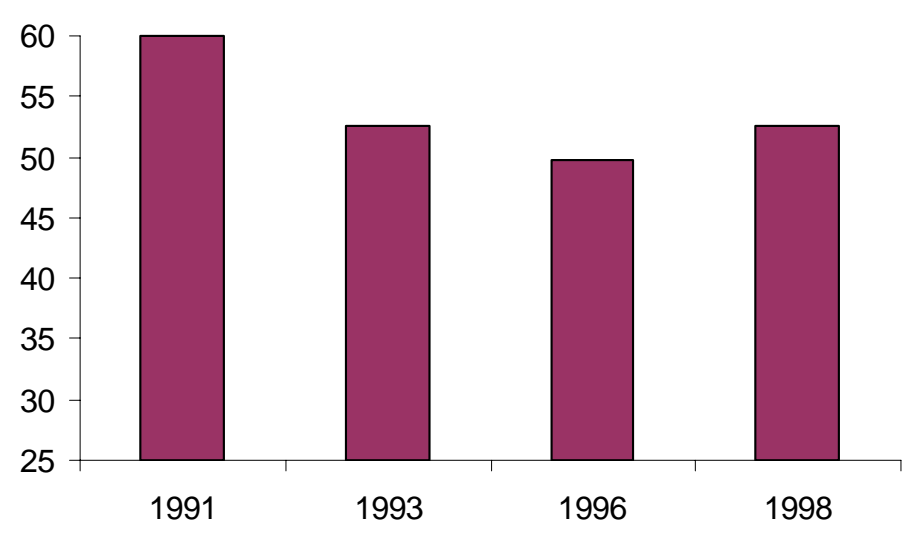


Figure 3: Poverty headcount coefficients just before and just after onset of crisis (Source: Povcal, Uses same dates as for Table 1 (c)).

Headcount before and just after onset of crisis

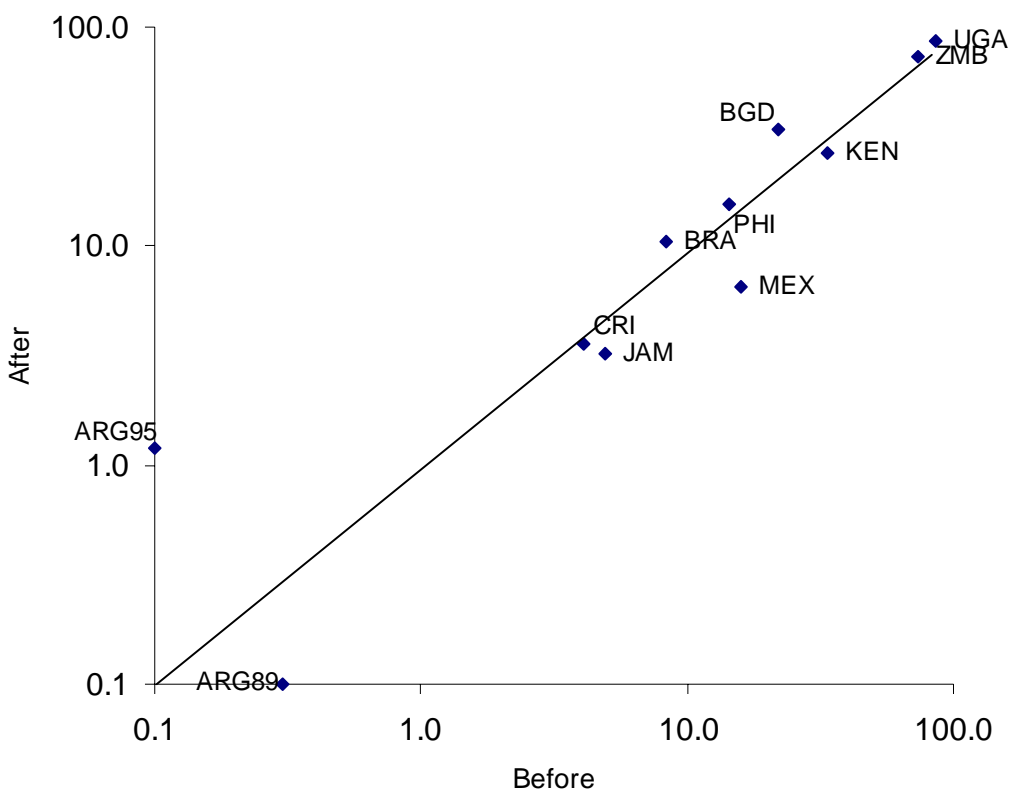


Figure 4: Gini coefficients before any crisis and just after end of crisis (Source: Table 1 (a))

\section{Gini before and just after end of crisis}

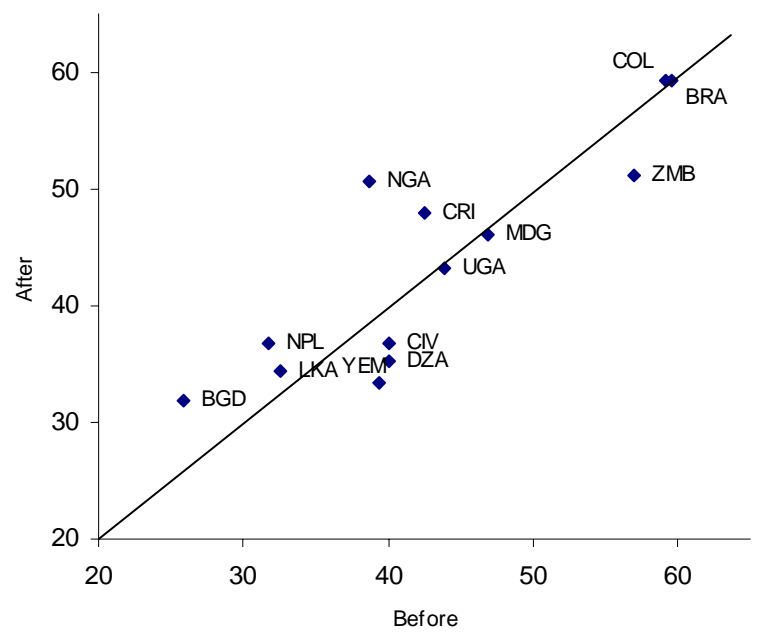

Figure 5: Gini coefficients just before and just after onset of crisis (Source: Table 1 (a))

Gini before and just after onset of crisis

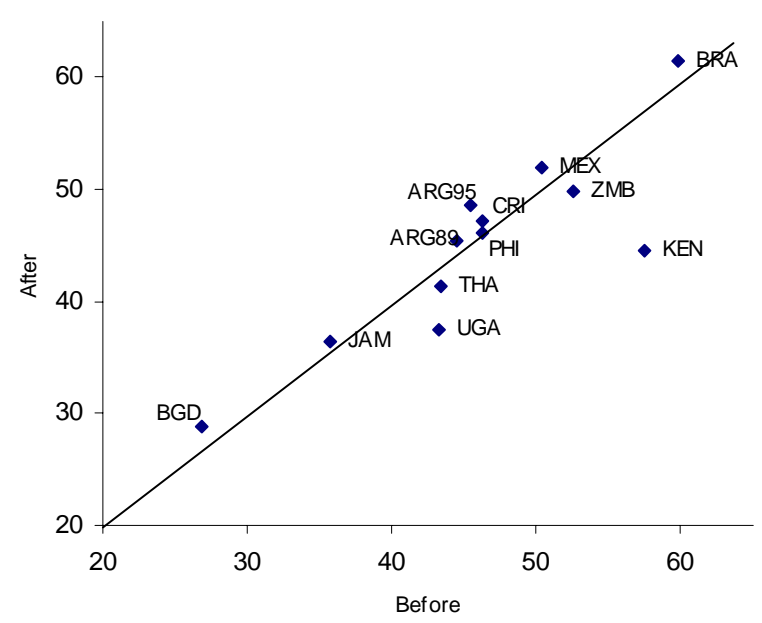


Annex: Indonesia

\section{Annex: A closer look at one crisis: Indonesia}

The Indonesian crisis that began in the second half of 1997 and deteriorated rapidly in the months following December 1997, is a promising case in which to examine relative impact on different groups. This is not simply because of the depth of the crisis (real GDP declined by $13 \%$ in 1998 and remained unchanged in 1999 before beginning a recovery; the estimated fiscal cost of 55 percent of GDP equals the highest ever recorded). But it is also because household level impact is unusually well documented. In particular three extensive Indonesia Family Life Surveys (IFLS) are well-timed for analyzing trends in poverty in the immediate aftermath of the crisis. ${ }^{24}$ About 2000 households were surveyed in August-December 1997 (IFLS2), just before food prices started to increase sharply, and almost all were resurveyed one year later (IFLS2+), by which time nominal food prices had reached a plateau at almost 3 times their pre-crisis level. A third wave, IFLS3, was fielded in late 2000. Another important source, with much larger samples but a less detailed questionnaire, is the annual "core" and three-yearly full national SUSENAS socio-economic survey. Rural conditions have also been tracked in a periodic survey of 120 households in each of 100 villages, conducted 5 times in the period 1997-99.

Unfortunately, the Indonesian surveys do not ask questions on usage of financial services or on other aspects that would help us directly identify and track the financial sector channels of causality discussed in Section 2.3. ${ }^{25}$ As such, timing is the main identifier of the effects of the Indonesian crisis, though an alternative, discussed in A.3 below, is to model the impact of certain price and other changes on household income and opportunities.

\section{A.1 Short-term impact}

To summarize, data from late 1998 indicate a large increase in poverty rates, but there may have been a reduction in income inequality, although there are some indications of a relatively severe welfare impact on the already poor. However, measuring these changes is highly sensitive to the price index used to deflate household income or expenditure data. With such a wide range of estimates of the increase in income poverty, it is prudent to look at non-income indicators also. While poor households may have lost a somewhat smaller proportion of their spending power, they cut back somewhat more on schooling, especially primary schooling, than did the non-poor.

\footnotetext{
${ }^{24}$ Selected major waymarks in the Indonesian crisis are as follows. August 14, 1997: rupiah peg abandoned (followed by heightened pressure on the currency as corporates scramble to cover their FX exposure); October 31: IMF \$40 billion agreement unveiled; November 1: 16 banks closed leading to bank run. December: concerns over Suharto's health push rupiah and stock market sharply lower - by end-1997 Rupiah has lost over 58 percent of its value since mid-year. Moodys downgrades Indonesia sovereign debt to Ba1 - a junk rating. January 6, 1998: announcement of expansionary budget incompatible with IMF program; rupiah collapses, losing (again) half of its remaining value over a five-day period (later recovering somewhat), food and other prices jump, panic buying reported. January 27: partial debt moratorium announced together with guarantee of depositor funds. January till mid-February: Food and anti-Chinese riots. May 21: following weeks of riots in which several hundred died, Suharto steps down. July 1998: Rupiah weakens sharply again in July, recovering gradually to a new plateau by October. June 1999: Parliamentary elections. It should be noted that the financial crisis was accompanied by a severe drought from mid-1997 which helped trigger smog-creating forest fires. These factors, uninfluenced by the financial crisis were associated with a 4\% decline in rice output in 1997, and a further 5\% decline in 1999. Total direct cost of the forest fires to Indonesia has been estimated at 2.5\% of GDP (Barber and Schweithelm, 2002). The forest fires also had health impacts.

${ }^{25}$ In this context the reported resilience of Indonesia's main microfinance lender BRI through the crisis, both in terms of microfinance loan loss experience and growth in microdeposits, is intriguing (Patten et al. 2001). A similar pattern was reported for Bolivia (Vogelgesang, 2001).
} 
Because of the violent fluctuations in the exchange rate and in internal prices, the appropriate deflator is quite uncertain. Tradable prices, including that of most foodstuffs, generally increased more quickly than non-traded. Frankenberg et al. (1999 - FTB) report results based both on the Indonesian Central Statistics Bureau (BPS) urban price series and on the separate price series collected as part of the IFLS process. The IFLS price series suggest higher inflation by about 15 percentage points, and accordingly imply a much larger increase in poverty. Both series imply a sharp decline in mean and median real per capita consumption expenditure (PCE), by $39 \%$ (mean) and 21\% (median) for the adjusted figures, and by $24 \%$ (mean) and $2 \%$ (median) for the BPS series (FTB, Table 2.1). The fact that the mean percentage decline is so much higher than the median alerts us to disproportionately higher declines at higher deciles and is the first indication that income declines are not concentrated among the poor. Such large percentage declines in both mean and median PCE imply sharply rising poverty rates. ${ }^{26}$ The IFLS uses a national poverty line and reports headcount poverty doubling on the adjusted inflation figures, but increasing by only about a third if the official inflation series is used (FTB, Table 2.2). Suryahadi et al. (2003) arrive at a higher set of headcount estimates, but which show a similar rate of increase in the headcount from $15 \%$ at mid-1997 to 33\% at end-1998. (see e.g. their Figure 2).

A separate question is how the already poor have fared during the crisis. Suryahadi et al. (2000) calculated the change in real expenditures by quintile in two waves of the large SUSENAS household budget survey: February 1996 and February 1999. Real expenditure fell for all quintiles, but progressively less for poorer quintiles (6 percent for the bottom compared with $24 \%$ for the top - their Table 2). Inequality measures based on these calculations therefore show declining inequality in the crisis. ${ }^{27}$ Nevertheless, there are indications that important expenditures were relatively severely constrained by those in the lowest quartile. For instance, secondary school (age 13-19) enrolment fell in all deciles, but by more (51 to $45 \%$ ) in lowest decile households than in the rest - though the fall in the second decile (74 to 67\% ) is larger in absolute numbers and not much less proportionately. Primary school enrolment also fell, but by a statistically significant amount (93\% to 88\%) only for the lowest decile (FTB, Table 4.1, 4.2).

Patterns of healthcare usage changed sharply during the crisis. It appears that both relative price and quality of public healthcare services deteriorated, and many households substituted private suppliers. But there are indications ${ }^{28}$ that the price barrier was too high for lowest income households to make this substitution. Overall decline in usage of public healthcare facilities was identified by the researchers as a worrying likely source of future health problems (FTB p. 59). However, there is little indication in the data of a deterioration in self-reported health status, or in the relationship of health status to income level (FTB Tables 7.3, 7.4). The statistically significant reductions in the proportion of children with stunting (FTB Table 7.5), limit the extent to which the effect of trend improvements in nutrition and healthcare on the condition of the poor were immediately interrupted by the crisis. Nevertheless, the IFLS healthcare professionals reported a systematic deterioration in respondents' overall health status with, apparently, the largest deterioration in the lowest income categories (FTB p. 87 and Table 7.11).

\footnotetext{
${ }^{26}$ Declines in median hourly wage rates are larger than those reported for PCEs (, suggesting consumption smoothing, though whether this employed savings or borrowing is not known (FTB Table 3.2).

Participation in paid employment did not change much, but there was a considerable increase in female participation in unpaid (family) work.

${ }^{27}$ For the shorter period 1997-8, measuring the immediate impact on the panel of households in IFLS2 and 2+, Thomas and Frankenberg (2005) report that the top quartile showed the largest percentage declines in PCE; the bottom quartile also suffered large percentage declines, with the middle income groups relatively unaffected. As measured by the standard deviation of $\log$ PCE, inequality declined.

${ }^{28}$ The relationships here are not all statistically significant (FTB, Table 5.3, 5.4).
} 


\section{A.2 Medium-term impact}

Strauss et al. (2004) brings the story forward by two years to the end of 2000. Strikingly, poverty rates appear to have stabilized and even fallen. ${ }^{29}$ Using a different poverty line to that employed in FTB ${ }^{30}$ Strauss et al estimate (Table 3.1) that the headcount fell from $17.7 \%$ in 1997 to $15.9 \%$ three years later. The difference is not statistically significant given the modest sample size, but there was also a fall in each of four age groups in both urban and rural areas. ${ }^{31}$

This is a dramatic recovery from the sharp worsening of poverty measured in 1998 (in IFSL2+). And it is confirmed by the synthetic set of estimates presented by Suryahadi et al. (2003), who estimate that poverty headcount peaked at 33 percent in November 1998, before falling back to $15 \%$ by August 2000 and to $10 \%$ by February 2001 (13\% in February 2002). A fall in the share taken by rice in household budgets is another indicator of improved conditions between 1997 and 2000 (Strauss et al. Table 3.2).

Furthermore, plotting the cdf of personal consumer expenditure for 1997 and 2000, it becomes evident that the incidence of poverty has fallen for almost any chosen poverty line (up to a multiple of any standard poverty lines). ${ }^{32}$ However, the 2000 cdf does not dominate the 1997 one everywhere - certain middle-income groups saw a reduction in real living standards between the two periods. From this data, two years after the crisis, it would be hard to argue that the poor had been particularly badly hit in living standards.

Interestingly, more households reported a perceived deterioration in standard of living since 1997 than reported an improvement. But this is not because of perceived deterioration at the bottom: only one in twenty of those who reported themselves as being in the second-from bottom category had slipped to the bottom category by 2000. (In contrast, three of every four persons who reported themselves as having been in the second-from top category in 1997 had slipped at least one notch by 2000.) From this perspective too, therefore, it seems that living standard declines between 1997 and 2000 were not particularly concentrated among the poor (Strauss et al., Tables 4.1 and 4.2).

There were sizable declines in median real wages in the private sector and overall (median public sector wages actually increased). ${ }^{33}$ The declines were smaller than those reported for 1997-98, suggesting a recovery. On the other hand, there was a sharp increase in rates of employment, especially among women and younger men and applying both to paid and unpaid employment. Thus real wages had fallen, but household incomes had been maintained through more work, often through adding an additional part-time job (Strauss et al., Table 5.1).

A similar story is suggested by the 2000 data on educational enrolment. Enrolment was generally up, having recovered all of the initial loss in 1998, and by a statistically significant amount in the

\footnotetext{
${ }^{29}$ Suryahadi et al., using different surveys, arrived at the conclusion that poverty peaked around August 1998 (Table 7)

${ }^{30}$ The poverty lines used by FTB and by Strauss et al. are not a single rupiah figure across Indonesia, but instead are set at a multiple of the local cost of a standard national food basket.

${ }^{31}$ Classifying households into urban and rural and by region, 19 different headcount figures are obtained, of which 13 show declined, two statistically significant. Only rural households in West Nusa Tenggara (Lombok and Sumbawa islands) shows a significant increase. Much the same pattern is observed for the poverty gap and squared poverty gap (Strauss et al. Tables 3.5).

${ }^{32}$ And the difference is statistically significant at least up to standard poverty lines. (Strauss et al. Figures $3.1,3.2)$.

${ }^{33}$ Indeed, the cdf of overall employee hourly real wage rates was uniformly lower in 2000 than in 1997. Self-employment increased and the cdf of hourly earnings of the self-employed rose.
} 
Annex: Indonesia

case of poor primary school age (7-12) children (Strauss et al. Table 6.1). The recovery in enrolment is confirmed in the May 1999 wave of the 100-villages survey, which also documents a lower incidence by then of child labor (Cameron, 2000).

Height for age and weight for age cumulative distribution functions also seem to show improvements at the left-tail in 2000 relative to 1997. The proportion of children in different age groups showing up in the unfavorable tail of a standardized distribution of these variables generally declines and for amounts that are statistically significant for the older children (36-59 months) (Strauss et al. Table 7.1). Only in respect of weight for height and for very young girls (3-17 months) is there an adverse movement that even approaches statistical significance (Strauss et al. Table 7.3). However, and importantly, self-reported and expert-reported health conditions of children appear to have deteriorated significantly; however, the deterioration is not significantly associated with income/expenditure levels (Strauss et al. Table 7.6). The lower use of some types of public health facility by poor children persisted to 2000; but the fact that health status had not been affected induced some analysts to question the effectiveness of these facilities (Strauss et al. p. 258).

Of course, even if there was an improvement in conditions in 2000 relative to 1997, that does not imply that the effects of the crisis had been completely eliminated by then. The steady improvements of previous decades had been interrupted, and the current state was evidently lower than a projection of previous trends.

\section{A.3 An alternative view of the Indonesia crisis: simulating a micro-macro model}

One clear drawback of the before-and-after approach to judging the impact of the crisis is that it neither decomposes the impacts of different elements of the crisis - devaluation, relative price change, credit constraints, etc., nor does it cleanly abstract from other exogenous developments, such as the drought. Robilliard et al. (2002) present a sophisticated analysis along these lines using a 38 -sector CGE model of the economy linked to a 10,000 household microsimulation model calibrated on the 1996 SUSENAS survey. ${ }^{34}$

Strikingly, these authors argue that income inequality (Gini) was increased by the crisis - albeit only slightly in aggregate (larger increases in rural than in urban inequality being offset by a narrowing of the urban-rural gap). Working through the modeled effect of observed price changes in the period 1997-98 on household incomes they simulate an increase in inequality. The model sees the credit crunch in particular as factors that would have worked to increase inequality. The contrast between this simulation and what was apparently a decline in the estimated Gini coefficient from surveys taken before and the crisis must then be interpreted as reflecting either (i) a degree of adaptability, not captured in the model, of poorer Indonesian households and the markets in which they operate to the wage-price and other shocks, or (ii) other non-crisis factors working to offset the modeled increase in Gini.

\footnotetext{
${ }^{34}$ Adopting a narrower focus, but again avoiding reliance on the possible sampling error introduced by comparing before and after household surveys, Levinsohn et al. (1999) simply look at price changes and how they differentially impacted poor and non-poor at their initial basket of goods. Their approach is to calculate a Laspeyre's price index for January 1997 and October 1998 for the consumption basket of each of 58,000 households sampled in the SUSENAS survey of 1993. The urban and rural results prove to be quite different. Taking account of owner-occupied housing and self-produced food consumption, the rural poor (bottom decile) experienced a price increase of $73 \%$, compared with $84 \%$ for the rural rich. But in the urban poor saw a price increase of $128 \%$, compared with only $89 \%$ for the urban rich. The compensating variations calculated on 1996 SUSENAS data by Berry and Levinsohn (1999), and including an allowance for product substitution based on Deaton's (1997) methodology, yield much lower costs, but distributionally similar results. The data source here does, however, not provide income information.
} 